\title{
Water- and Energy-Efficient Appliances for Circular Water Economy: \\ Conceptual Framework Development and Analysis of Greenhouse Gas \\ Emissions and Water Consumption
}

Supporting Information

\section{Content}

7 Texts

17 Figures

6 Tables

Tony Geglio ${ }^{1}$, Terrianna Bradley ${ }^{1}$, Tia Williams ${ }^{1}$, Shan $Z_{\text {hou }}^{2}$, David Watkins ${ }^{1}$, Daisuke

Minakata $^{1 *}$

${ }^{1}$ Department of Civil and Environmental Engineering, Michigan Technological University

${ }^{2}$ Department of Social Sciences, Michigan Technological University

*Corresponding author. Phone: +1-906-487-1830; fax: +1-906-487-2943, 1400 Townsend Drive,

Houghton MI, 49931, U.S.

Email address: dminakat@mtu.edu 
Text S1: Estimation of emission factors for electric power generation using electric power generation resource mix and fuel source LCA emissions factors

This study seeks to consider the regional and projected variations of emissions related to electric power generation including the contribution of renewable electricity to the overall green-house gas emissions. The range of emission factors for electric power generation was therefore estimated using resource mix data from the PJM Interconnection Regional Transmission Organization (PJM) ${ }^{1}$ website, the EIA Monthly Energy review (MER) ${ }^{2}$, and the EPA eGRID dataset $^{53}$. The emission factors for the individual fuel types both renewable and non-renewable were adapted from the NREL LCA systematic review and harmonization ${ }^{4}$ summarized on the NREL website ${ }^{5}$ which includes estimates from the IPCC report ${ }^{6}$ reported with the units of grams $\mathrm{CO}_{2}$ equivalent greenhouse gas emissions per $\mathrm{kWh}$ of electricity generation $\left(\mathrm{g} \mathrm{CO}_{2} \mathrm{e} / \mathrm{kWh}\right)$. The website summarizes and reports the central tendencies output from numerous meta-analytical studies of the life cycle green-house gas inventories of electric power fuel sources using a methodology which systematically reviews and harmonizes the values for the various factors accounted for by the published literature. The emission factors used in this study are converted to $\mathrm{kg} \mathrm{CO}{ }_{2} \mathrm{e} / \mathrm{kWh}$.

\section{Resource mix data Sources:}

The PJM Hourly Generation by Fuel Type dataset from 2016 to 2021 (Figure S1) was downloaded from the PJM Regional Transmission Organization (PJM RTO) data miner $2^{1}$. Summaries of climate, total load, and proportion residential, commercial, and industrial use are available on the 2020 PJM Load Forecast Report, and hourly generation mix data was downloaded from the PJM Data Miner.

The projection of electric power generation mix data for 2021-2050 were downloaded from the Energy Information Administrations' 2021 Annual Energy Outlook (AEO 2021) 7. The 2019 eGRID $^{3}$ resource mix estimates for the eGRID sub-regions across the U.S. were downloaded from the eGRID data explorer.

The projections of electric power emission factors used for the study were the AEO 2021 reference case and the AEO 2021 low-cost renewables projection (Figure S2).

Emission factors for coal, oil, and natural gas were cross checked using plant-level data from the US Energy Information Administration (EIA) ${ }^{4}$. The EIA estimate for the 2019 plant-level electric power emissions factor for electricity generation in the U.S. was 0.92 pounds of $\mathrm{CO}_{2} / \mathrm{kWh}$ or $0.417 \mathrm{~kg} \mathrm{CO}_{2} / \mathrm{kWh}$. The 2019 EPA eGRID data for regions across the U.S. ranges from 233 to $1708 \mathrm{lbs}$. $\mathrm{CO}_{2} \mathrm{e} / \mathrm{kWh}\left(0.105 \text { to } 0.775 \mathrm{~kg} \mathrm{CO}_{2} \mathrm{e} / \mathrm{kWh}\right)^{8}$. The U.S. weighted average from eGRID data is calculated to be $889 \mathrm{lbs} . \mathrm{CO}_{2} \mathrm{e} / \mathrm{kWh}(0.403 \mathrm{~kg} \mathrm{CO} 2 \mathrm{e} / \mathrm{kWh})$ in 2019 . The resource mix methodology which uses the LCA estimates of the various fuel source consistently results in slightly larger emission factors due to the account of upstream factors contributing to the overall emissions.

Using the resource mix methodology applied to the PJM generation mix data, we calculated an electric power emissions factor of $0.415 \mathrm{kgCO}_{2} \mathrm{e} / \mathrm{kWh}$ from 2019 PJM. The U.S. Average resource mix from the EIA monthly energy review resulted in $0.432 \mathrm{kgCO}_{2} \mathrm{e} / \mathrm{kWh}$, and the U.S. average resource mix from the eGRID dataset calculated $0.428 \mathrm{kgCO}_{2} \mathrm{e} / \mathrm{kWh}$ for electric power generation. The range of electric power emission factors from the eGRID dataset ranges 
from $0.136 \mathrm{kgCO}_{2} \mathrm{e} / \mathrm{kWh}$ in NYUP where gas, nuclear, and hydro-electric power dominate the resource mix to 0.826 in HIOA where petroleum-based fuel dominates electric power generation. To calculate the total emissions factor for electric power generation using resource mix data, we apply the following formula:

Electric Power EF $\left(\mathrm{kg} \frac{\mathrm{CO}_{2}}{\mathrm{kWh}}\right)=$

$\sum$ Fuel source Percent of total generation $\times$ Fuel Source Emission Factor

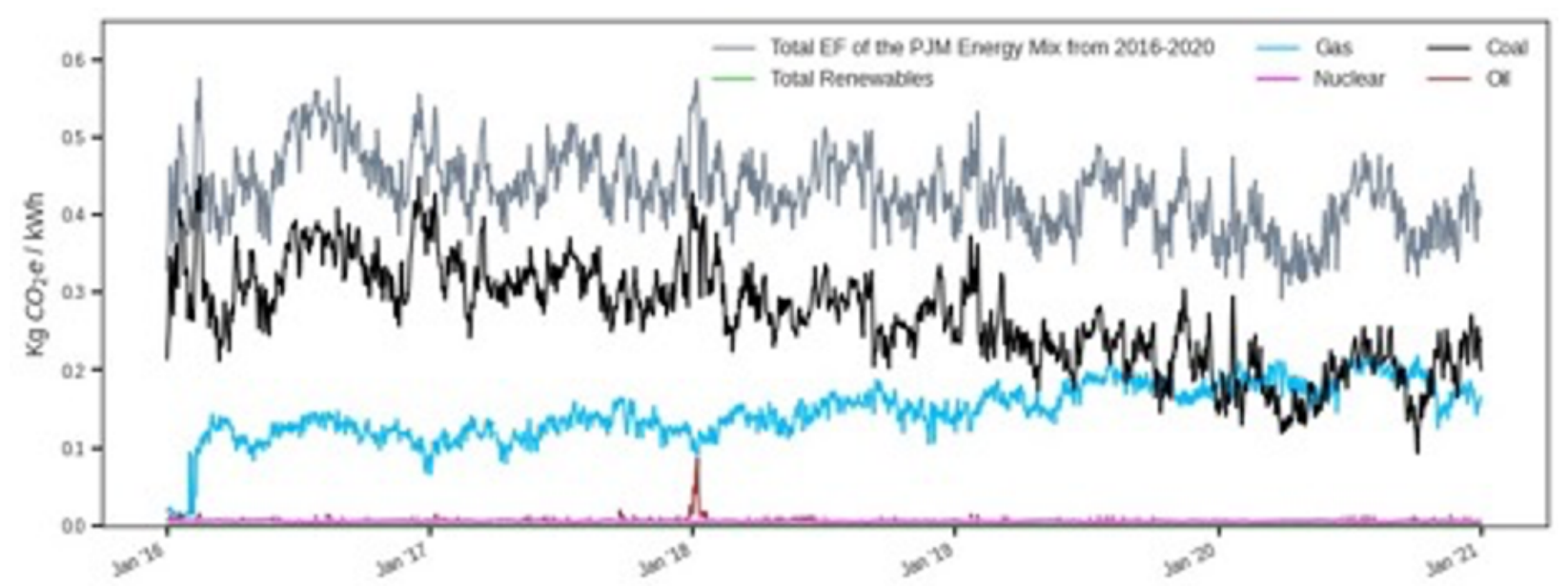

Figure S1: PJM hourly generation by fuel type data from 2016 to 2021 converted to time series electric power emission factor using the resource mix methodology. The total emissions factor varies from 0.4 to $0.55 \mathrm{CO}_{2} \mathrm{e} / \mathrm{kWh}$ and shows an overall decreasing trend from 2016 to 2021 due to the increased use of natural gas. The figure also shows that natural gas and coal have dominated the proportional contributions to the total emissions per kWh of energy during this time period. 


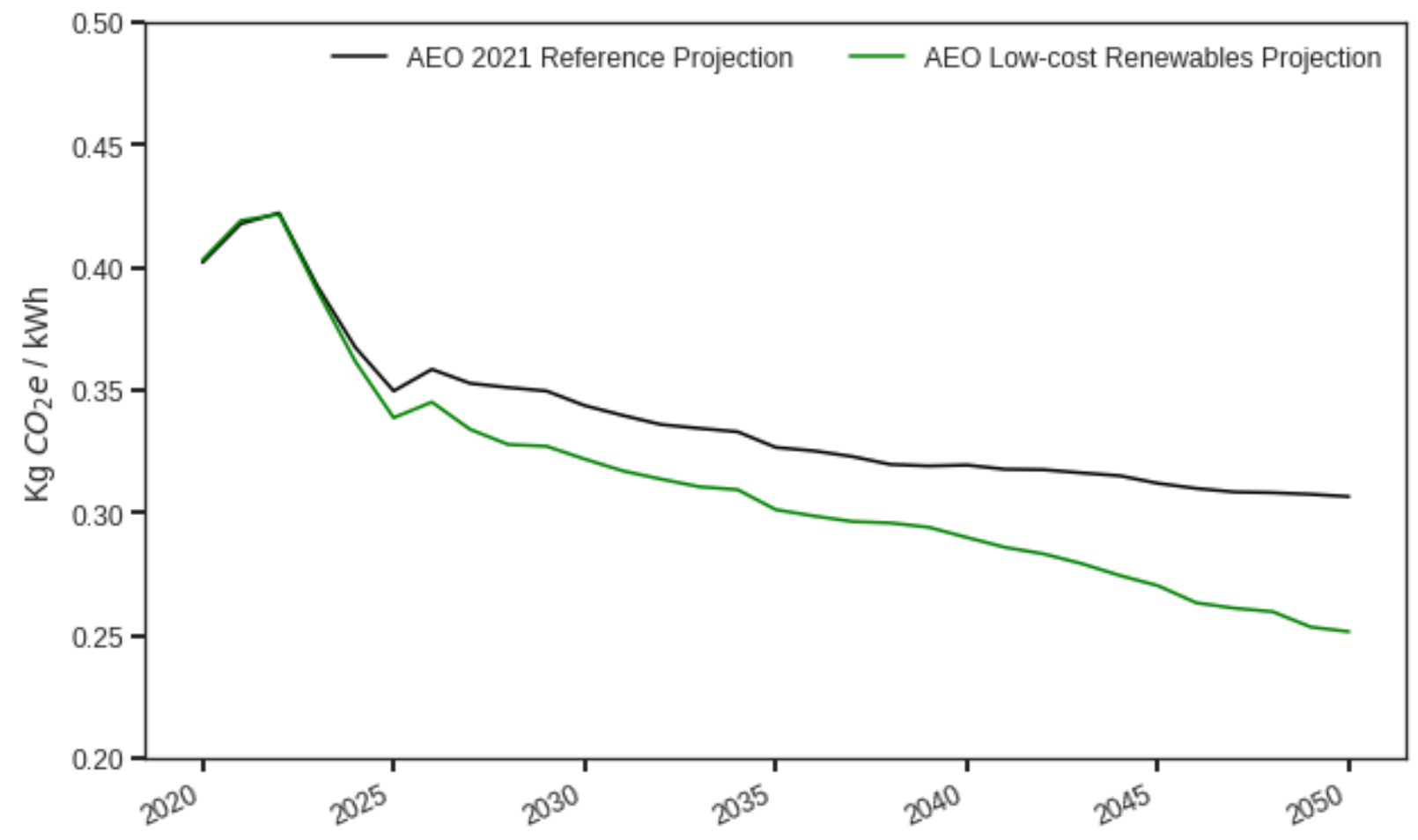

Figure S2: AEO 2021 reference case and the AEO low-cost renewables projection of the electric power emission factor using the resource mix projections in these scenarios.

Table S1: Fuel source emission factors estimated for major electric power generating fuels Fuel-source emissions factors adapted from $\quad$ EIA MER ${ }^{2}$ NREL 2019 resource

\begin{tabular}{|c|c|c|c|}
\hline Fuel Source & harmonization $^{5}$ & $\operatorname{mix}$ & \\
\hline Non-Renewables & $\left(\mathrm{kgCO}_{2} \mathrm{e} / \mathrm{kWh}\right)$ & $\begin{array}{l}\text { Percent of Total } \\
\text { Generation Mix }\end{array}$ & \\
\hline Coal & $0.980^{\mathrm{a}, 9}$ & $24.18 \%$ & \\
\hline Natural Gas & $0.487^{\mathrm{b}, 10}$ & $37.25 \%$ & \\
\hline Petroleum & $0.840^{11}$ & $0.430 \%$ & \\
\hline Nuclear & $0.012^{\mathrm{c}, 12}$ & $20.41 \%$ & \\
\hline Renewables & & & $\begin{array}{c}\text { Percent of } \\
\text { Renewable } \\
\text { Mix }\end{array}$ \\
\hline Biomass & $0.043^{\mathrm{d}, 13}$ & $0.71 \%$ & $4.0 \%$ \\
\hline Geo-thermal & $0.040^{\mathrm{e}, 14}$ & $0.38 \%$ & $2.2 \%$ \\
\hline Solar & $0.020^{f, 15}$ & $1.80 \%$ & $10.2 \%$ \\
\hline Wind & $0.012^{\mathrm{g}, 16}$ & $7.45 \%$ & $42.4 \%$ \\
\hline Hydro-electric & $0.012^{\mathrm{h}, 17}$ & $7.23 \%$ & $41.1 \%$ \\
\hline
\end{tabular}




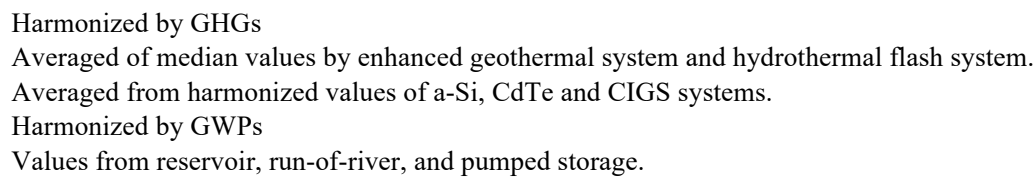

\section{Text S2: Calculation procedures of emission and water consumption per}

\section{each household appliance}

The Household Systems Analysis tool was developed to estimate the annual contribution of GHG emissions $\left(\mathrm{asCO}_{2} \mathrm{e}\right)$ and water consumption from major energy and water consuming systems in a typical household. The energy consuming systems included in the tool are space heating, space cooling, water heating, clothes drying, cooking, refrigeration, lighting, and electronics. Water consuming systems are faucets, toilets, showers, and landscape irrigation, and typical quantities of cooking and drinking water per capita. Systems that consume both energy and water include dishwashing and clothes washing.

The following three major categories determine the output of the household system'sbased annual emissions and water use and are described in this SI document: (1) Electric power emission factor ( $\mathrm{kg} \mathrm{CO} 2 \mathrm{e} / \mathrm{kWh}$ ). Various regional, U.S. average, and time-series based emissions factors for the U.S. electric power sector were estimated; (2) System efficiency (performance metrics vary by system). The tool accepts input from the user specifying each systems level of efficiency that correspond to a performance metric and an associated cost of that system; and (3) Climate Data provides estimates of heating, cooling, and irrigation requirements.

\section{Climate Data}

Annual heating and cooling degree days are useful to estimate a buildings energy consumption for heating over a year. The degree days for a period is the number of days multiplied by a temperature variation relative to a base temperature, and the U.S. standard base temperature is $65^{\circ} \mathrm{F} .{ }^{18}$ Heating degree data is available through NOAA ${ }^{19}$ and other local and regional sources. The climate data used are representative of Northern Illinois. The heating and cooling $\Delta \mathrm{t}$ are useful to estimate the number of days heating is required in a given year. Values were estimated by computing the average baseline temperature variation throughout the year. For cooling days this is the average temperature variation for the months below the baseline $65^{\circ} \mathrm{F}$. The average peak monthly rainfall $(\mathrm{R})$ and reference evapotranspiration (Eto) are useful to determine the theoretical landscape irrigation requirement in a given year. WaterSense provides a free Microsoft Excel spreadsheet, Water Budget Tool V 1.0420, that estimates these values based on a zip code.

\section{Emissions per unit of heat energy for household primary fuel use including natural gas, propane, and fuel oil, and the heat content of electricity}

Natural Gas:

A comparative life-cycle greenhouse gas study by Fulton, et al., $2011^{21}$ with the Worldwatch Institute provides a top-down life cycle analysis reporting the emission estimate for natural gas with the IPCC's 100-year global warming potential, analyzing the production, processing, and fuel combustion related emissions for a baseline year of 2008 domestic production. The study reports that other recent bottom-up life cycle analysis indicate shale gas production to be 
potentially more GHG intensive than conventional natural gas. Using EPA's 2011 methodology for the 100-year GWP time horizon, updating the fugitive methane emissions estimates in the production for natural gas systems the study reports a substantial increase in the upstream component over the 2010 methodology. The study reports the life cycle GHG inventory of natural gas delivered to consumers, total upstream emissions are $19.2 \mathrm{~kg} \mathrm{CO}_{2} \mathrm{e} / \mathrm{MMBtu}$ compared to $12.0 \mathrm{~kg} \mathrm{CO} 2 \mathrm{e} / \mathrm{MMBtu}$ using 2010 methodology. The same fuel combustion value of 53.1 was used in both methods totaling $72.3 \mathrm{~kg} \mathrm{CO}_{2} \mathrm{e} / \mathrm{MMBtu}$ for natural gas consumed. A 2014 Report by the National Energy Technology Laboratory ${ }^{22}$ reports an upstream cradle to gate emissions factor including natural gas extraction, processing, and transportation for the average 2010 U.S. domestic mix to be $8.86 \mathrm{~kg} \mathrm{CO}_{2} \mathrm{e} / \mathrm{MMBtu}$. The same paper presents a comparison of natural gas upstream GHG emissions from four additional studies; Spath \& Mann, 200, Jaramillo et al., 2007, Burnham et al., 2011, and Jiang et al. 2011 on the basis of 100-year GWP time horizon while recognizing a full-boundary reconciliation was not performed. Burnham et al., $2011^{23}$ pay particular attention to shale gas production and associated methane emissions reporting shale gas emissions to be $6 \%$ lower than conventional natural gas using the GREET LCA methodology. Burnham reports the upstream GHG emissions from shale gas to be 14.2 and conventional natural gas $17.2 \mathrm{~g} \mathrm{CO}_{2} \mathrm{e} / \mathrm{MJ} \mathrm{NG}$ energy delivered (14.98 to $18.15 \mathrm{~kg}$ $\mathrm{CO}_{2} \mathrm{e} / \mathrm{MMBtu}$ ) for the 100-year time horizon. More recently fugitive GHG emissions for natural gas have been updated and studies modeled fugitive emissions from equipment that is common to all natural gas operations. While the range of emission factors was reported in literature, the most conservative estimate of $72.3 \mathrm{kgCO}_{2} \mathrm{e} / \mathrm{MMBtu}$ of natural gas energy used by consumers was used for the systems analysis.

Heath et. al. ${ }^{24}$ presented a summary of reported and harmonized results of numerous peer-reviewed LCAs reporting the use of shale, conventional, and unconventional sources of U.S. domestic natural gas for electricity generation on the basis of $\mathrm{CO}_{2}$ equivalent $\mathrm{GHG}$ emissions per unit electricity production. The median estimates of shale (plus unconventional) and conventionally produced natural gas from the eight evaluated studies differ slightly. The grouped (i.e., shale plus unconventional and conventional plus domestic) median value was $0.493 \mathrm{kgCO}_{2} \mathrm{e} / \mathrm{kWh}$ compared to that of conventional, $0.475 \mathrm{kgCO}_{2} \mathrm{e} / \mathrm{kWh}$. For an aggregated estimate of the U.S. natural gas market, imported natural gas ranged from 4.5 million cubic feet in 2006 to under 3 million in 2020, while U.S. domestic production ranged from 25 million in 2006 to over 40 million cubic feet in 2020. Assuming that the majority of natural gas consumed in the U.S. is domestic, the aggregated emissions factor was estimated based on the market share of U.S. domestic natural gas production ${ }^{25}$. In this natural gas production, the conventional sources were from conventional gas wells, and the unconventional sources were from shale gas, coal bed gas, and oil well gas. Using the median emission factor by Heath et. al. ${ }^{24}$, the weighted average emission factors were estimated to be $0.482 \mathrm{kgCO}_{2} \mathrm{e} / \mathrm{kWh}$ in 2006 and 0.490 $\mathrm{kgCO}_{2} \mathrm{e} / \mathrm{kWh}$ in 2020 , respectively.

For comparison, the stationary Combustion Emission Coefficient for natural gas reported by the $\mathrm{EIA}^{28}$ is $53.07 \mathrm{~kg} \mathrm{CO}_{2} / \mathrm{MMBtu}$ with $1 \mathrm{~g} \mathrm{CH}_{4} / \mathrm{MMBtu}$ and $0.1 \mathrm{~g} \mathrm{~N}_{2} \mathrm{O} / \mathrm{MMBtu}(0.025$ $\mathrm{CO}_{2} \mathrm{e} / \mathrm{MMBtu}$ and $0.0298 \mathrm{CO}_{2} \mathrm{e} / \mathrm{MMBtu}$ respectively using the 100-year GWP) reported by the EPA which is consistent with combustion estimates that were used in the studies by Fulton and Burnham. For the purpose of our study which aims to provide the most holistic estimate of the greenhouse gas emissions, the Fulton estimate of $72.3 \mathrm{~kg} \mathrm{CO}_{2} \mathrm{e} / \mathrm{MMBtu}$ using the EPA 2011 methodology incorporating a broader impact of fugitive methane emissions is considered for primary fuel use of natural gas delivered and used by residential customers. 
Propane and Fuel Oil:

Upstream GHG emissions relative to propane and fuel oil were also analyzed. According to the RECS, about $4.9 \%$ of U.S. homes use fuel oil or kerosene for home heating, and $4.2 \%$ use propane. Data from the EcoInvent life-cycle inventory database ${ }^{26}$ was collected and the 100 -year average GWP using SimaPro to calculate approximate upstream emissions for propane and heating oil. Propane was calculated to have an upstream emissions of $0.841 \mathrm{~kg} \mathrm{CO}_{2} \mathrm{e} / \mathrm{kg}$ of fuel, and heating fuel oil was calculated $0.545 \mathrm{~kg} \mathrm{CO} 2 \mathrm{e} / \mathrm{kg}$ of fuel.

Using data from the EIA $^{27}$ for the heat content of fuels and the approximate mass per gallon of each fuel, the upstream emissions coefficients per unit of energy were calculated 20.32 and $13.26 \mathrm{~kg} \mathrm{CO} 2 \mathrm{e} / \mathrm{MMBtu}$ for propane and fuel oil respectively. The combustion emissions $\mathrm{EIA}^{28}$ are 63.07 and $73.16 \mathrm{~kg} \mathrm{CO} / \mathrm{MMBtu}$ for propane and fuel oil respectively, and the EPA eGRID database accounts methane and nitrous oxide factors as the same for both totaling $0.25 \mathrm{~kg}$ $\mathrm{CO}_{2} \mathrm{e} / \mathrm{MMBtu}$. The emission factors per unit of heat energy considered for the study are therefore 83.64 and $86.67 \mathrm{CO}_{2} \mathrm{e} / \mathrm{MMBtu}$ for propane and fuel oil respectively. Thermal conversion factor for electricity: Heat Content of Electricity delivered to customers: 1 $\mathrm{kWh}$ of electricity $=3,412 \mathrm{Btu}$ of heat energy. ${ }^{29}$

\section{Household Parameters}

Residents per household: 2.53

According to survey data compiled by the US Census Bureau ${ }^{30}$; Bureau of Labor Statistics, the average number of residents per household was 2.53 in 2020 .

Normalized household heating requirement: 5 Btu/HDD/sf

The normalized household heating requirement is the approximate energy demand for space heating a typical household which can vary by household size, and local or regional estimations of heating degree days. A generic value for the normalized household heating requirement relative to heating degree days and household size is estimated using data from the EIA Residential Energy Consumption Survey (RECS) ${ }^{31}$.

In the latest 2015 RECS data ${ }^{31}$ the 18.1 million Midwest homes in the East North Central census division represent the largest region in which all homes require heating. Households have an average of 2,051 sf of heated space and consumed on average 55.4 million Btu of energy for space heating (considering all fuel types) and 66.2 million Btu is required for heating with natural gas as the primary heating source which accounts for $73 \%$ of households in this region. According to the EIA Monthly Energy Review data, in 2015 there were 6,165 heating degree days in the East North Central division. A generic estimate of household heating requirement can then be estimated with this data to range from 4.4 to $5.2 \mathrm{Btu} / \mathrm{HDD} / \mathrm{sf}$. An estimated 5

$\mathrm{Btu} / \mathrm{HDD} / \mathrm{sf}$ was used in this study to allow for a flexible input of climate and household size.

House heating/cooling area: 1,790 sf

The heated area in the RECS data ranges depending on housing type, location relative to the city, and income. Goldstein et al. $2020^{32}$ did a comprehensive analysis of the RECS data and determined the highest density of single family detached household sizes range from 150 to 200 $\mathrm{m}^{2}\left(1,600-2,150 \mathrm{ft}^{2}\right)$ of floor space. 


\section{Household Systems efficiency calculations}

\section{Performance metrics}

Data for the household systems appliances were collected from the Department of Energy CCMS database and Energy Star Certified Product Data Sets and APIs ${ }^{33}$. Performance metrics refer to quantities that gauge the efficiency of the system.

\section{Flexible Input Parameters}

Flexible input parameters are assumed quantities that can be altered by the user to better represent a specific household. The flexible parameters used in the systems analysis were generalized using available data and statistics. For example, a typical household heated area (sf) was estimated using the EIA Residential Energy Consumption Survey (RECS) ${ }^{34}$. Climate statistics for proportions of heating degree days were estimated from NOAA's 1981-2010 U.S. Climate Normals ${ }^{38}$. Typical appliance operation such as clothes wash cycles per year were gathered from the Department of Energy's Standards and Test Procedures for consumer products which are administered by the Energy Policy and Conservation Act (EPCA) ${ }^{35}$.

\section{Output}

Output in the Household Systems Emissions analysis are calculated values related to the systems consumption of energy, water, and carbon dioxide emissions.

\section{Gauge Quantities}

Additional calculations were added such as the required furnace wattage, furnace or heat pump on-cycle ratios, and total heating days per year evaluated to determine if the flexible input parameters are reasonable.

\section{Example calculations for the emissions related to heating and cooling.}

Space heating

Annual fuel utilization efficiency (AFUE), \%, was used as a performance metric for space heating ${ }^{40,41}$. The AFUE value is the ratio of annual heat output of a space heater to the total annual fuel energy consumed by a furnace ${ }^{36}$.

Net heating emission, $\mathrm{kg} \mathrm{CO}_{2} \mathrm{e} /$ year, and electricity use if electricity is chosen, $\mathrm{kWh} / \mathrm{year}$, were calculated and reported as outputs. The annual net heating emission was the product of annual electricity usage, $\mathrm{kWh} / \mathrm{year}$, and electric power emission factor $\left(\mathrm{CO}_{2} \mathrm{e} / \mathrm{kWh}\right)$ that was selected from the scenarios of energy resources mix.

Emissions $\left(\mathrm{kg} \frac{\mathrm{CO}_{2} \mathrm{e}}{\mathrm{year}}\right)=$ Electricity use $\left(\frac{\mathrm{kWh}}{\mathrm{year}}\right) \times$ Electric power emissions factor $\left(\frac{\mathrm{CO} 2 \mathrm{e}}{\mathrm{kWh}}\right)$

where, the electricity use shown in equation (S3) was calculated based on the home energy demand in equation (S4) and the heat content of electricity. It is noted that a coefficient for calculating household annual heat energy demand, Btu/year, of a model household of a given floor space incorporated a climate component based on heating degree days (HDD). The 
coefficient was referred as the heating coefficient. The regional values of both the HDD and household fuel consumption values for residential heating were compiled from the RECS ${ }^{34}$. using the normalized household heating requirement. The total heating time was calculated as shown in equation (S5) based on the furnace capacity, Btu/h, that was in the range from 30,000 to $120,000 \mathrm{Btu} / \mathrm{h}^{1}$ and the annual home energy demand in equation (S4). The furnace capacity was corrected to the approximated useful heat output of a furnace measured in Btu/ $\mathrm{h}^{37}$. The furnace size was based on the total heat output in $\mathrm{Btu}^{37}$. For example, the actual heat output of a furnace rated at 100,000 Btu with a 95\% AFUE provides approximately $95,000 \mathrm{Btu} / \mathrm{hr}$ to a home ${ }^{36}$.

Electricity Use $\left(\frac{\mathrm{kWh}}{\text { year }}\right)=\frac{\text { Home energy demand }\left(\frac{\mathrm{Btu}}{\mathrm{year}}\right)}{3412\left(\frac{\mathrm{Btu}}{\mathrm{kWh}}\right)}$

Home energy demand $\left(\frac{B t u}{\text { year }}\right)=$

$\underline{\text { Heating coefficient }\left(\frac{\text { Btu }}{\text { HDD x sf }}\right) \times \text { house size }(s f) \times \text { Heating Degree Days }\left(\frac{\text { HDD }}{\text { year }}\right)}$

Fuel utilization efficiency (UEF)/100

Total heating time $\left(\frac{\text { hours }}{\text { year }}\right)=\frac{\text { Furnace capacity }\left(\frac{\text { Btu }}{\text { hour }}\right)}{\text { Home energy demand }\left(\frac{\text { Btu }}{\text { year }}\right)}$

For the gauge quantities, the annual total heating days, days/year, were calculated by dividing the annual heating degree days (HDD) at a test location by the average heating temperature difference from $65^{\circ} \mathrm{F}^{18}$. The HDD were estimated using the NOAA reported 1981-2010 U.S. Climate Normals ${ }^{38}$. The average heating temperature difference was estimated by calculating the monthly average temperature difference from a baseline temperature of $65^{\circ} \mathrm{F}$ during the heating months, or those months with average temperature below $65^{\circ} \mathrm{F}^{39}$.

Total heating days $\left(\frac{\text { days }}{\text { year }}\right)=\frac{\operatorname{HDD}\left(\text { days } \mathrm{x} \Delta^{\circ} \mathrm{F} \text { below 65) }\right.}{\text { Average heating } \Delta \mathrm{t}\left(\Delta^{\circ} \mathrm{F} \text { below } 65\right)}$

The average hourly furnace operation time (Avg. on cycle time per hour), $\mathrm{min} / \mathrm{hr}$, was determined by the ratio of total heating time approximated from the furnace size and home energy demand in equation (S5) to the total heating days approximated from on-climate data in equation (S6) as shown in equation $(\mathrm{S} 7)^{39}$.

Avr. on cycle time per hour $\left(\frac{\mathrm{min}}{\mathrm{hr}}\right)=\frac{\text { Total heating time }\left(\frac{\text { hours }}{\text { year }}\right) \times 60\left(\frac{\mathrm{min}}{\mathrm{hour}}\right)}{\text { Total heating days }\left(\frac{\text { days }}{\text { year }}\right) \times 24\left(\frac{\text { hours }}{\text { day }}\right)}$

To gauge the furnace size, the electric furnace required wattage, $\mathrm{kW}$, was determined based on the calculated average power consumed by the furnace and the calculated total heating time, hrs/year, as shown in equation $(\mathrm{S} 8)^{40}$. 
Electric furnace required wattage $(\mathrm{kW})=\frac{\text { Electricity use }\left(\frac{\mathrm{kWh}}{\mathrm{year}}\right)}{\text { Total heating time }\left(\frac{\mathrm{hrs}}{\text { year }}\right)}$

The average on cycle time, heating days, and furnace wattage estimates did not impact the estimated energy consumption. Instead, these provided a tool for users to gauge whether the calculated outputs were composed of reasonably ranged physical quantities of the system such as heating time and wattage. For example, we estimated an electric coil furnace consumed 12,958 $\mathrm{kWh} / \mathrm{yr}$ under typical Midwest climate based on the home energy demand in equation (S4). Given that the typical furnace ratings ranged from 30,000 Btu to 120,000 Btu, we used 50,000 Btu as an input value for this. Based on the ratio of electricity used to heating time estimated from the climate data (i.e., $884 \mathrm{hrs} /$ year), we determined $15 \mathrm{~kW}$ (i.e., required wattage if a household used only an electric coil furnace). This gauge quantity can be compared to either with household specific measurements, or the typical ranges in the CCMS ${ }^{50}$, the Energy Star database $^{41}$, and other public domain data such as a home heating guide ${ }^{1}$.

\section{Heat pump for supplemental heating}

The performance metric of a heat pump system was the heating seasonal performance factor (HSPF) that is the system's heat input capacity per unit electricity (Btu/W-h $)^{45}$ and accounts operation under varying outdoor temperatures as well as part-load impacts (i.e., effects of running short cycles under mild conditions $)^{42}$. The net emissions as an output were calculated as shown in equation (S9) from the adjusted electricity conventional heat, $\mathrm{kWh} / \mathrm{year}$, heat pump electricity, $\mathrm{kWh} / \mathrm{year}$, and emission factor, $\mathrm{CO}_{2} \mathrm{e} / \mathrm{kWh}$. The adjusted electricity from conventional heat was the calculated electricity consumed resulting from heat input from only conventional electric heating coils ${ }^{43,44}$ that was referred as auxiliary or backup and may be calculated as shown in equation (S10) where a conversion factor, 3,412 Btu/kWh, was included. The electricity for heating with a heat pump, $\mathrm{kWh} /$ year, was the product of the total heat pump heating time and the heat pump running power, $\mathrm{kW}$, as shown in equation (S11).

Net emissions $\left(\mathrm{kg} \frac{\mathrm{CO}_{2} \mathrm{e}}{\text { year }}\right)=\left[\right.$ Adjusted electricity from conventional heat $\left(\frac{\mathrm{kWh}}{\text { year }}\right)+$ Electricity for heat pump heating $\left.\left(\frac{\mathrm{kWh}}{\text { year }}\right)\right] \times \mathrm{EF}\left(\frac{\mathrm{CO}_{2} \mathrm{e}}{\mathrm{kWh}}\right)$

where

Adjusted electricity from conventional heat $\left(\frac{\mathrm{kWh}}{\text { year }}\right)=\frac{\text { Home energy demand }\left(\frac{\mathrm{Btu}}{\mathrm{year}}\right)\left(<40^{\circ} \mathrm{F}\right)}{3,412\left(\frac{\mathrm{Btu}}{\mathrm{kWh}}\right)}$

The electricity for heating with a heat pump was determined by estimating the portion of the home energy demand that could be heated with a heat pump operating under the rated efficiency (i.e., HSPF) as shown in equation (S11).

Electricity for heat pump heating $\left(\frac{\mathrm{kWh}}{\text { year }}\right)=\frac{\text { Home energy demand }\left(\frac{\mathrm{Btu}}{\mathrm{year}}\right)\left(>=40^{\circ} \mathrm{F}\right)}{\operatorname{HSPF}\left(\frac{\mathrm{Btu}}{\mathrm{Wh}}\right) \times 1,000\left(\frac{\mathrm{Wh}}{\mathrm{kWh}}\right)}$ 
The portion of the home energy demand, Btu/year, when the outside temperature was at or above $40{ }^{\circ} \mathrm{F}$ indicated that a heat pump can provide $100 \%$ of the heat energy at the rated HSPF. The portion below $40^{\circ} \mathrm{F}$ was assumed to rely on the backup, or auxiliary heating coils. The percentage of heating days ( $\%$ of days) whose temperatures were above $40^{\circ} \mathrm{F}$ (e.g., $\left.30 \%\right)^{44}$ was used as a flexible parameter determined from regional climate data.

Home energy demand $\left(\frac{\mathrm{Btu}}{\text { year }}\right)\left(\geq 40^{\circ} \mathrm{F}\right)=$ Household heated area $(\mathrm{sf}) \times \frac{\mathrm{HDD}}{\mathrm{yr}} \times$

Heating coefficient $\left(\frac{\mathrm{Btu}}{\mathrm{HDD} \times \mathrm{sf}}\right) \times\left(\%\right.$ of heating days $\left.>40^{\circ} \mathrm{F}\right)$

Home energy demand $\left(\frac{\mathrm{Btu}}{\text { year }}\right)\left(<40^{\circ} \mathrm{F}\right)=$ Household heated area $(\mathrm{sf}) \times \frac{\mathrm{HDD}}{\mathrm{yr}} \times$

Heating coefficient $\left(\frac{\text { Btu }}{\text { HDD x sf }}\right) \times\left(1-\%\right.$ of heating days $\left.>40^{\circ} \mathrm{F}\right)$

To gauge the user input heating capacity and HSPF efficiency, we included the heat pump power that referred to the calculated power consumed by the appliance during the operation. Central heat pump capacities range from 18,000 to $60,000 \mathrm{Btu} / \mathrm{hr}^{45}$ and the wattage may be calculated using the efficiency rating as shown in equation $(\mathrm{S} 14)^{46}$.

Heat pump running power $(\mathrm{kW})=\frac{\text { Heating capacity }\left(\frac{\mathrm{Btu}}{\mathrm{hr}}\right)}{\text { Heating seasonal performance factor }\left(\frac{\mathrm{Btu}}{\mathrm{Wh}}\right) \times 1,000 \frac{\mathrm{Wh}}{\mathrm{kWh}}}$

The average time on cycle time per house was determined by the ratio of the total heating time to the total heating days as shown in equation $(\mathrm{S} 15)^{47}$.

Average on cycle time per hour $\left(\frac{\text { min }}{\text { hour }}\right)=\frac{\text { Total heat pump heating time }\left(\frac{\text { hours }}{\text { year }}\right) \times 60\left(\frac{\text { min }}{\text { hour }}\right)}{\text { Total heat pump heating days }\left(\frac{\text { days }}{\text { year }}\right) \times 24\left(\frac{\text { hours }}{\text { day }}\right)}$

Finally, the total heat pump heating days were estimated as a time during the proportion of heating days that were greater than $40^{\circ} \mathrm{F}$ and less than $65^{\circ} \mathrm{F}^{44}$, indicating that a heat pump will be operating to produce household space heat.

Total heat pump heating days $\left(\frac{\text { days }}{\text { year }}\right)\left(40^{\circ} \mathrm{F}<\mathrm{T}<65^{\circ} \mathrm{F}\right)=\frac{\operatorname{HDD}\left(\text { days } \times \Delta \mathrm{t}^{\circ} \mathrm{F}\right) \times\left[\% \text { of days }>40^{\circ} \mathrm{F}\right]}{\text { Average heating } \Delta \mathrm{t}\left({ }^{\circ} \mathrm{F}\right)}$

In this case, the on-cycle time for the heat pump is estimated to be 26 minutes per hour during practical use. The power used by the heat pump while heating is calculated to be $3.9 \mathrm{~kW}$, and the total heat pump heating days 37 days per year by review of climate data that the Heat Pump can perform household heating for $30 \%$ of the total heating season,

\section{Central air-conditioning systems for space cooling}

The performance matrix of a space cooling system was the seasonal energy efficiency ratio (SEER) that referred to the ratio of output cooling energy, Btu, to electrical input energy, Watt$\mathrm{hr}^{41}$. 
Average cooling $\Delta \mathrm{t}=10^{\circ} \mathrm{F}$ (i. e., $75-65^{\circ} \mathrm{F}$ ) was estimated for Midwest U.S. ${ }^{38}$

On cycle time per hour $\left(\frac{\min }{\text { hour }}\right)=45$ was used for ideal cycle time for air conditioner ${ }^{48}$

The emissions from space cooling may be determined as a product of electricity use, $\mathrm{kWh} / \mathrm{year}$, and the electric power emission factor, $\mathrm{CO}_{2} \mathrm{e} / \mathrm{kWh}$, as shown in equation (S17). The running power as an output was determined by the ratio of SEER to the cooling capacity. The cooling capacity was the flexible input parameter and typically was 35,000 according to the DOE CCMS dataset $^{50}$.

Emissions $\left(\frac{\mathrm{kg} \mathrm{CO}_{2} \mathrm{e}}{\text { year }}\right)=$ Electricity use $\left(\frac{\mathrm{kWh}}{\text { year }}\right) \times$ Electric power emissions factor $\left(\frac{\mathrm{CO} 2 \mathrm{e}}{\mathrm{kWh}}\right)$

Running power $($ Watts $)=\frac{\operatorname{SEER}\left(\frac{\mathrm{Btu}}{\mathrm{W}-\mathrm{h}}\right)}{\operatorname{Cooling} \text { capacity }\left(\frac{\mathrm{Btu}}{\mathrm{h}}\right)}$

The total cooling days was determined by dividing the annual cooling days (CDD) by the temperature difference between the outside temperature and $65^{\circ} \mathrm{F}$ as shown in equation (S19)

Total cooling days $=\frac{\operatorname{CDD}(\text { days }) \times\left[\Delta^{\circ} \mathrm{F} \text { above } 65^{\circ} \mathrm{F}\right]}{\text { Averge Cooling } \Delta \mathrm{t}}$

The total on-time per year was determined by the total cooling days times on-cycle time, $\mathrm{min} / \mathrm{hr}$ as shown in equation $(\mathrm{S} 20)^{49}$.

Total on time $\left(\frac{\text { days }}{\text { year }}\right)=\frac{\text { Total cooling days }\left(\frac{\text { days }}{\text { year }}\right) \times \text { On cycle time }\left(\frac{\text { min }}{\text { hour }}\right)}{60\left(\frac{\min }{\text { hour }}\right)}$

Finally, the electricity use was determined by the total on-time and the running power, Watts.

Electricity use $\left(\frac{\mathrm{kWh}}{\text { year }}\right)=\frac{\text { Total on time }\left(\frac{\text { days }}{\mathrm{year}}\right) \times 24\left(\frac{\mathrm{hr}}{\mathrm{day}}\right) \times \text { Running power }(\text { Watts })}{1000\left(\frac{\mathrm{kW}}{\mathrm{Watt}}\right)}$

A rough calculation of residential sector emissions per capita using EIA data can be conducted from Monthly Energy Review ${ }^{4}$. A reported 958 million metric tons were emitted by the residential sector in 2019. Census data estimates a population of 328,314,000 in 2019 resulting in approximately $2,918 \mathrm{~kg} \mathrm{CO}_{2} /$ capita. For the average household of 2.53 persons, an average of $7,382 \mathrm{~kg} \mathrm{CO} /$ household is emitted. This value is within the ranges derived by the systems-based analysis. 


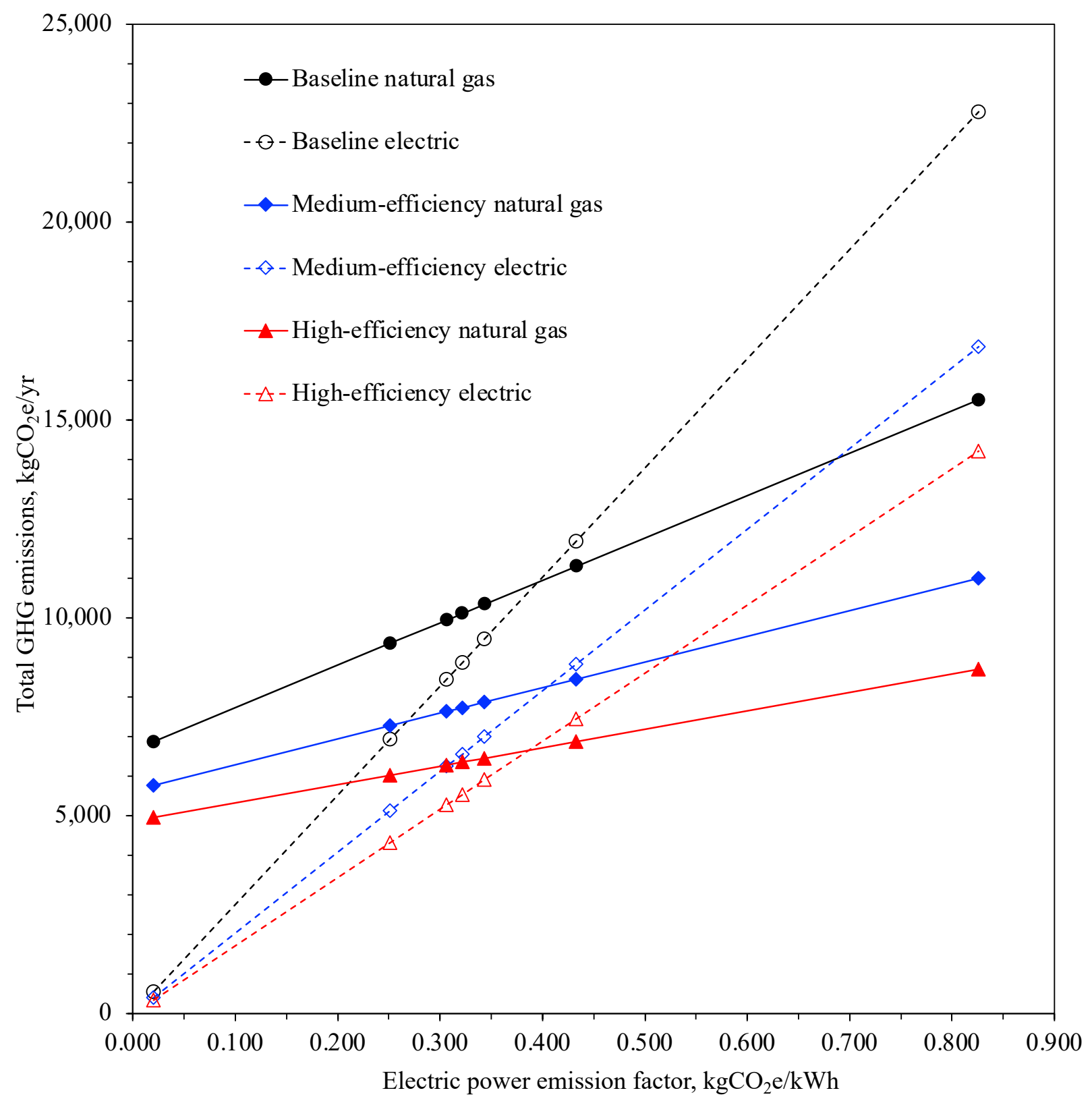

Figure S3: Calculated net household emissions based on various $\mathrm{CO}_{2}$ emission factors under seven scenarios: (1) $0.770 \mathrm{kgCO}_{2} \mathrm{e} / \mathrm{kWh}$ as the nation's largest value from eGRID subregion HIOA in Oahu; (2) $0.415 \mathrm{kgCO}_{2} \mathrm{e} / \mathrm{kWh}$ as the national average in 2019; (3) 0.344 and (4) 0.307 $\mathrm{kgCO}_{2} \mathrm{e} / \mathrm{kWh}$ as 2030 and $2050 \mathrm{AEO}$, respectively; (5) 0.322 and (6) $0.252 \mathrm{kgCO}_{2} \mathrm{e} / \mathrm{kWh}$ as 2030 and 2050 AEO low-cost renewable, respectively, and (7) $0.02 \mathrm{kgCO}_{2} \mathrm{e} / \mathrm{kWh}$ from the $100 \%$ of renewable use, with sources of natural gas and total electricity.

\section{Text S3: System Efficiency and Performance metric background}

The following histograms plot the efficiency parameters for household systems appliances to establish a baseline, efficient, and high efficiency range for our systems analysis. Product specifications and other appliance information was gathered from the DOE's Compliance Certification Management System (CCMS $)^{50}$ and the Energy Star certified appliance datasets ${ }^{51}$ 
and APIs. The CCMS database lists certified products meeting minimum standards defined by the Appliance and Equipment Standards Program. The datasets are not mutually exclusive; however, the CCMS is more comprehensive showing the range of typical specifications of products in the market, and Energy Star data showcases the high efficiency potential of products in the market.

\section{Space heaters (Centralized heating systems)}

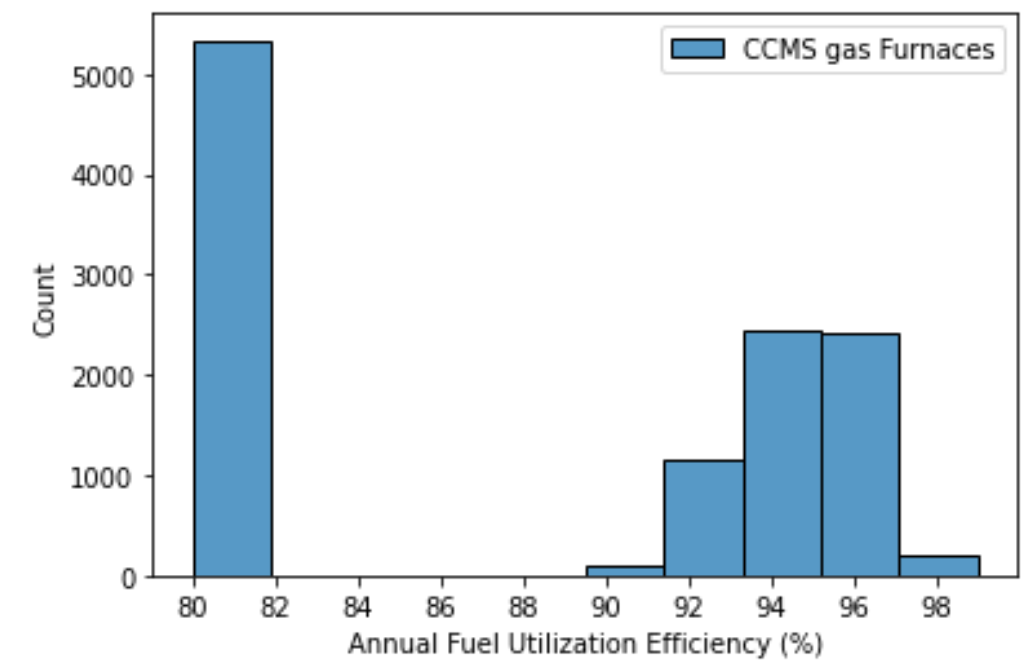

Figure S4: Histogram of counts of central gas space heating systems as a function of AFUE ratings $^{50}$

In the EIA Residential Energy Consumption Survey (RECS 2015) ${ }^{11} 57.7$ out of 118.2 million homes in the US reported Natural Gas as the primary heating fuel, and 40.9 million relied on electricity as the primary heating fuel. The remaining 19.6 million used fuel oil, propane, wood, or did not use heating equipment. In all Midwest census regions, greater than $60 \%$ of households report natural gas as their primary heating fuel. $76 \%$ of households in the Midwest reported using a central warm-air furnace as the main heating equipment.

Electrically fueled heat is approximately $100 \%$ efficient (100\% AFUE) meaning that $1 \mathrm{kWh}$ can be converted to 3,412 Btu of useful heat. Natural Gas furnaces are typically 80 to $95 \%$ efficient. The histogram in Figure S3 reflects the range of AFUE for products described as "nonweatherized gas furnaces" which represent $50 \%$ of 23,700 furnace models in the CCMS dataset $^{50}$. Electric furnaces have a $100 \%$ AFUE, and a typical range for gas furnaces is $80-95 \%$. Although we can assume electric heating converts $100 \%$ of electrical energy to heat energy inside the household, electric furnaces result in higher emissions in the systems analysis that accounts for the impact embedded in electric power generation.

\section{Air-source heat pump furnaces}

Home heating can be supplemented using a heat pump system to improve the efficiency of heat generated with electricity. The efficiency of a heat pump system is measured by its heating seasonal performance factor (HSPF) indicating the systems heat input capacity per unit electricity in (Btu/W-h).

Typical HSPF values for air-source heat pumps in the CCMS database range $8-12$ $\mathrm{Btu} / \mathrm{W}-\mathrm{h}$. Conventional electric heating equipment without an HSPF rating is assumed to have a 
3.412 Btu/W-h HSPF, meaning it generates 3,412 Btu for $1 \mathrm{kWh}$ electricity. The high HSPF will only be achieved during milder conditions and will otherwise rely on conventional heating coils. A conservative estimate of the threshold of reliance on a conventional heat source is for outside temperatures less than or equal to $40^{\circ} \mathrm{F}$.
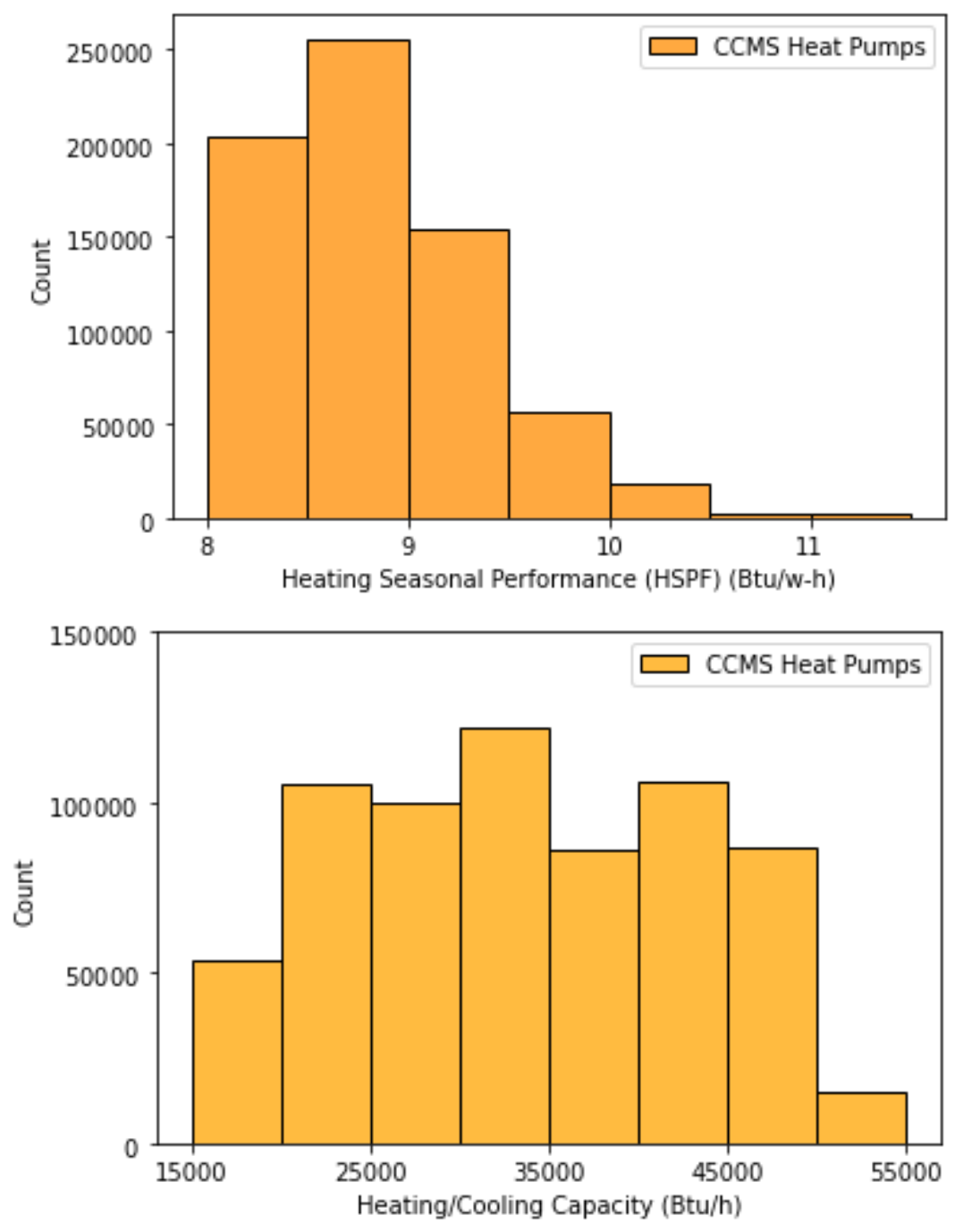


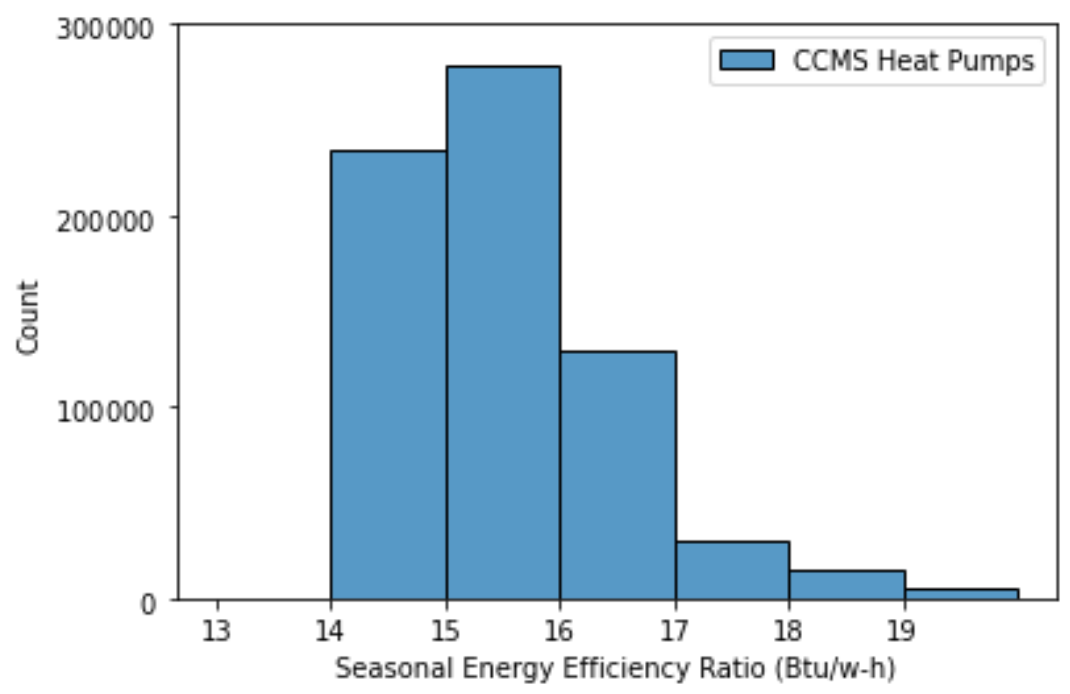

Figure S5: Histogram of counts of air-source heat pump systems

\section{Space coolers}

The efficiency of a central air conditioning system is rated by the Seasonal Energy Efficiency Ratio (SEER). SEER ratings range between 13 and $20 \mathrm{Btu} / \mathrm{W}-\mathrm{h}$ in the CCMS database. The minimum seer regulation of 13 was established on January 23, 2006 under the National Appliance Energy Conservation Act and minimum requirements are set to rise again in 2023. The CCMS database contains information on 4 million models of cooling units including household air conditioners and air-source heat-pump units. 3.3 million products are considered "Single-split-system" air conditioners, and the most common category of heat pumps classifying 700 thousand models are labeled as "single-split-system heat pumps." Only those categories are analyzed to avoid comparing different system types.

A median cooling capacity for air conditioners in the database is $35,000 \mathrm{Btu} / \mathrm{h}$ and is no apparent correlation between SEER and cooling capacity in the dataset. 

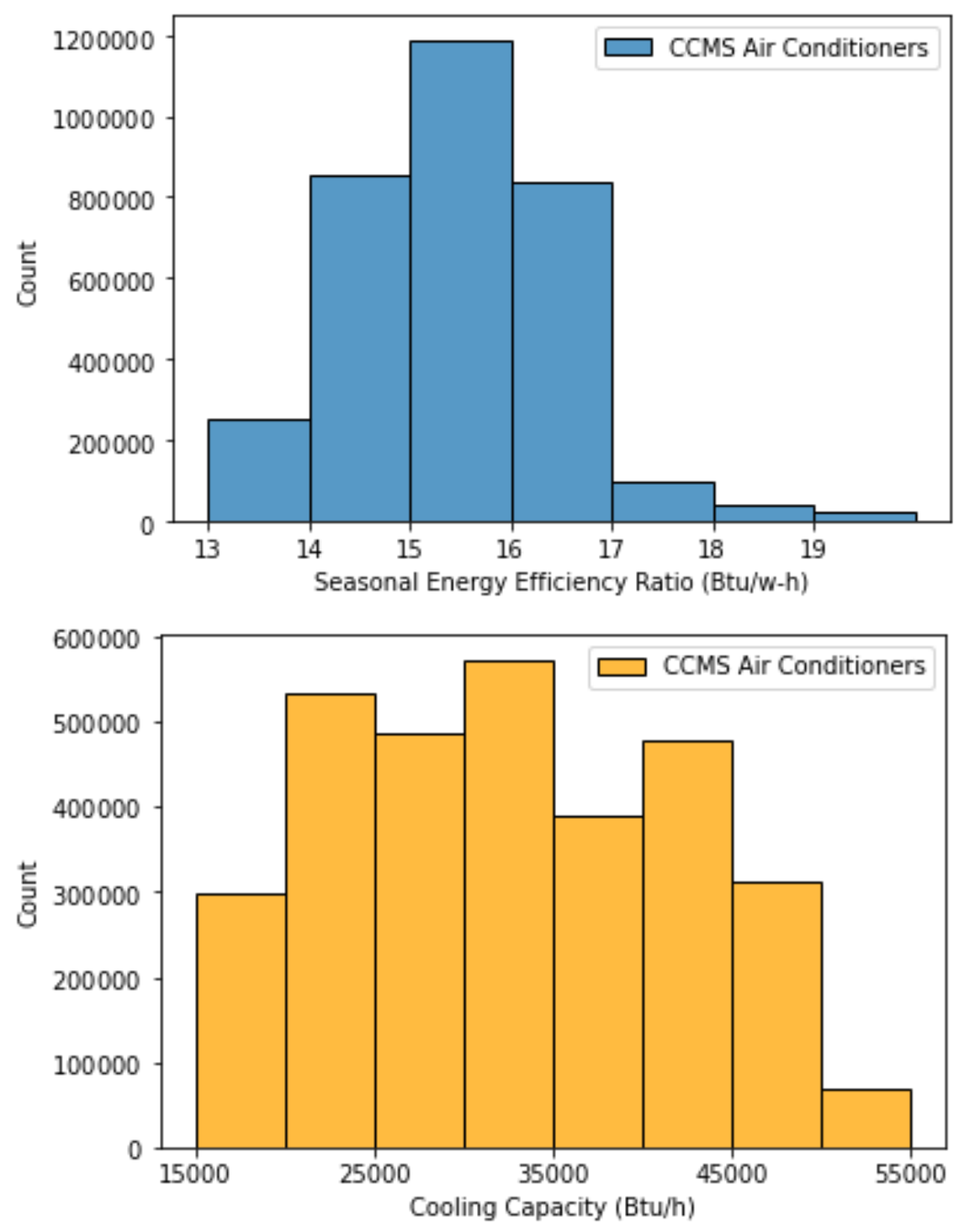

Figure S6: Histogram of counts of central air cooling systems as a function of cooling capacity 


\section{Water Heaters}
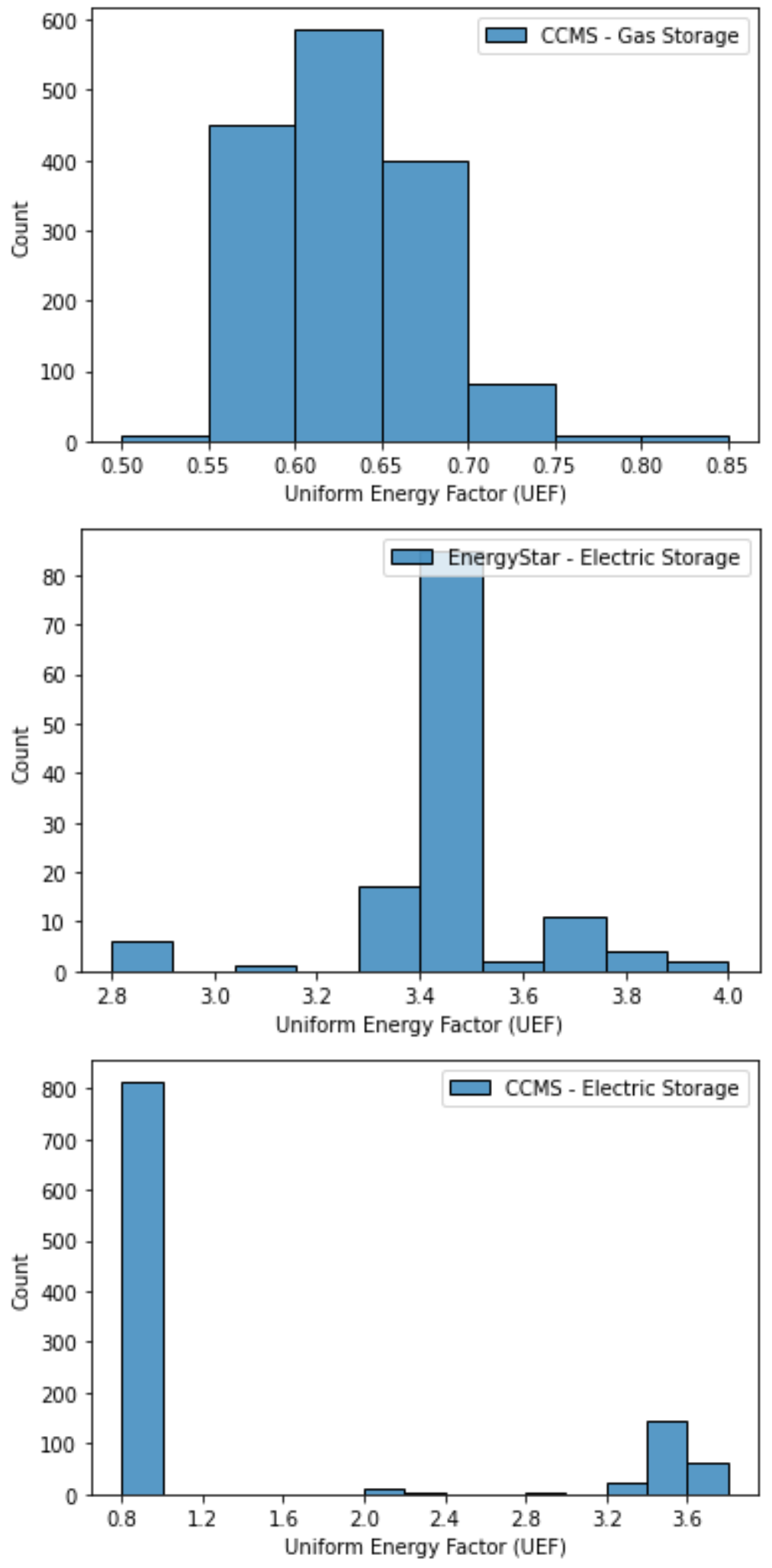

Figure S7: Histogram of counts of storage water heaters as a function of UEF ratings 


\section{Clothes Washers}

The Integrated Water Factor (IWF) and Integrated Modified Energy Factor (IMEF) are the two efficiency metrics that measure clothes washer efficiency for water and energy use per cycle. The "integrated values" are normalized by washer volume so that appliances of varying capacity can be compared. Washers with higher IMEF are more energy efficient, and lower IWF washers consume less water. Typical washers with baseline efficiency on the CCMS database have an IMEF of 1.5 and IWF of 6. Medium efficiency models have an IMEF of 3.1 and IWF of 4.25. The Energy Star certified washers have washers up to IMEF of 3.38 and IWF of 3.2 which represents a high efficiency scenario for this appliance. The Department of Energy clothes washer test procedure currently estimates 295 cycles (loads) per year in the March 2012 final rule updated based on 2005 RECS data. DOE test procedures for clothes washers are codified at appendices $\mathrm{J} 1$ and $\mathrm{J} 2$ in the code of federal regulations: 10 CFR part 430 subpart B.
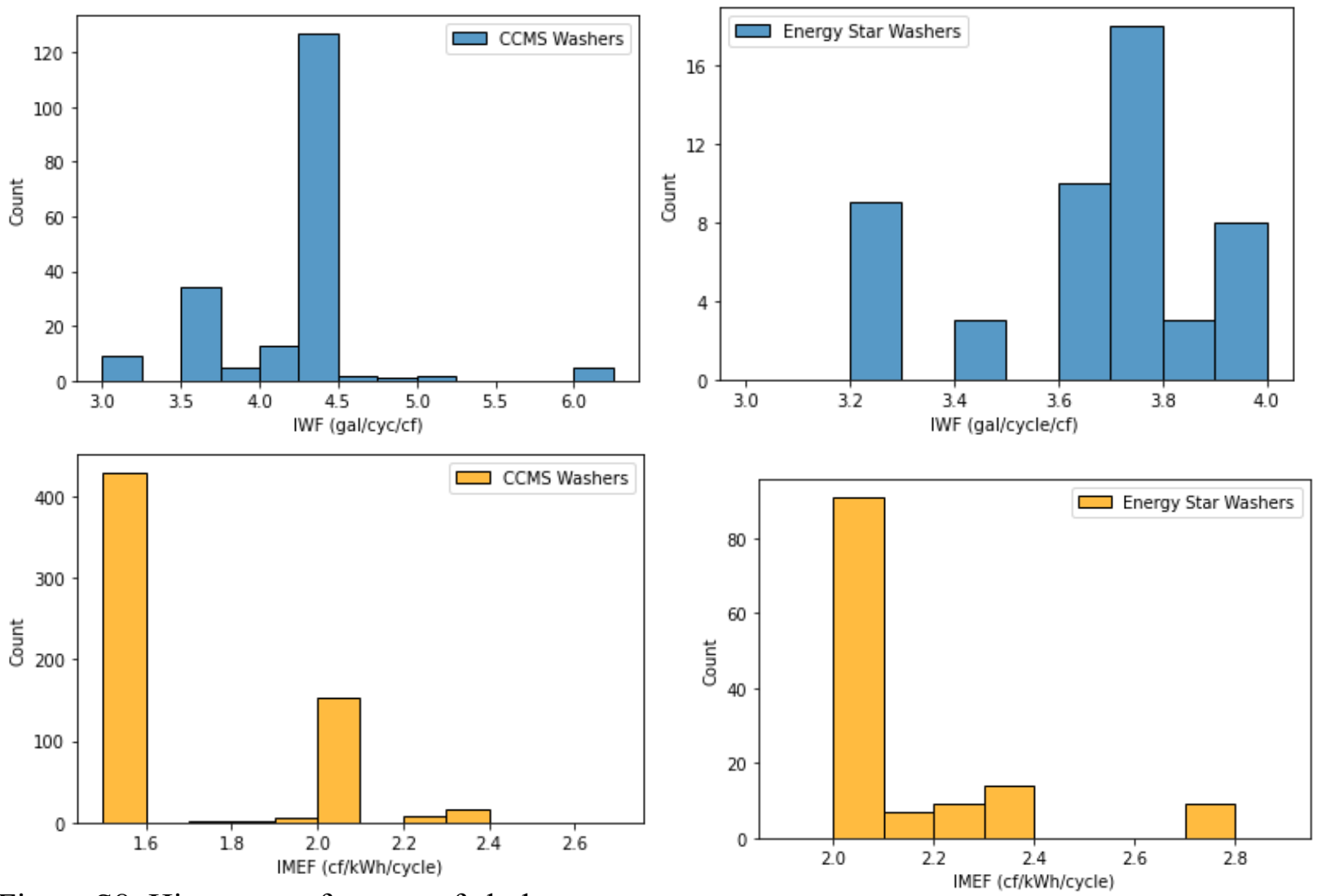

Figure S8: Histogram of counts of clothes washers as a function of IWF and IMEF ratings 


\section{Clothes Dryers:}
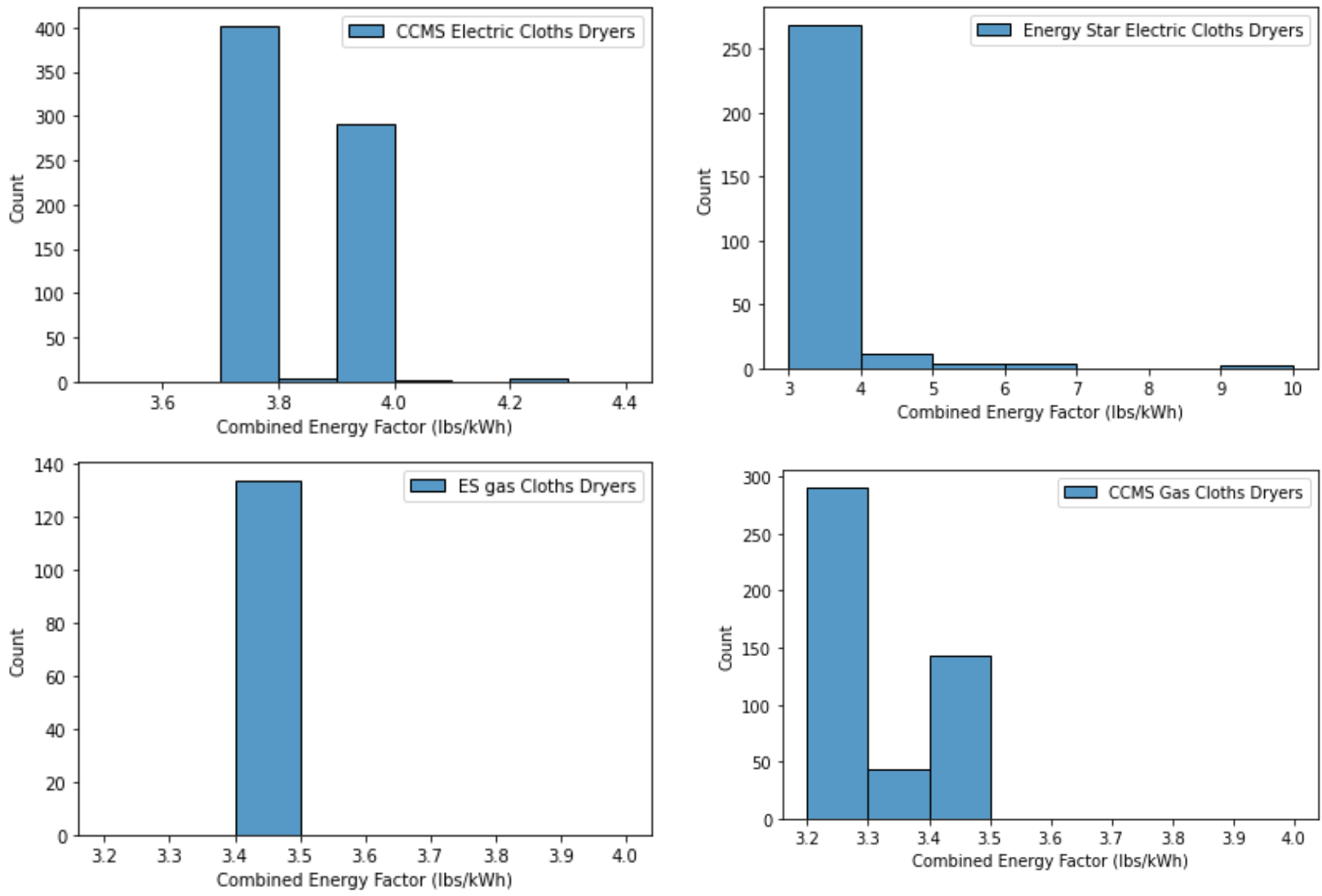

Figure S9: Histogram of counts of clothes dryers as a function of CEF ratings

\section{Electronics}

Less data is available on the DOE and Energy Star databases regarding household electronics; however, Energy Star does certify new televisions with superior efficiency, and the DOE lists parameters for over 2,800 televisions on the market ${ }^{33}$. The range of operating power for a 55inch TV is 50-160 Watts. Typical values for desktop computers were assumed to range 100-300 Watts including monitors, and laptops also vary consuming 15-60 Watts while in use. Some draw is associated with the electronics in off-mode so a continuous value of 3 -Watts of ambient draw was assumed for households. 

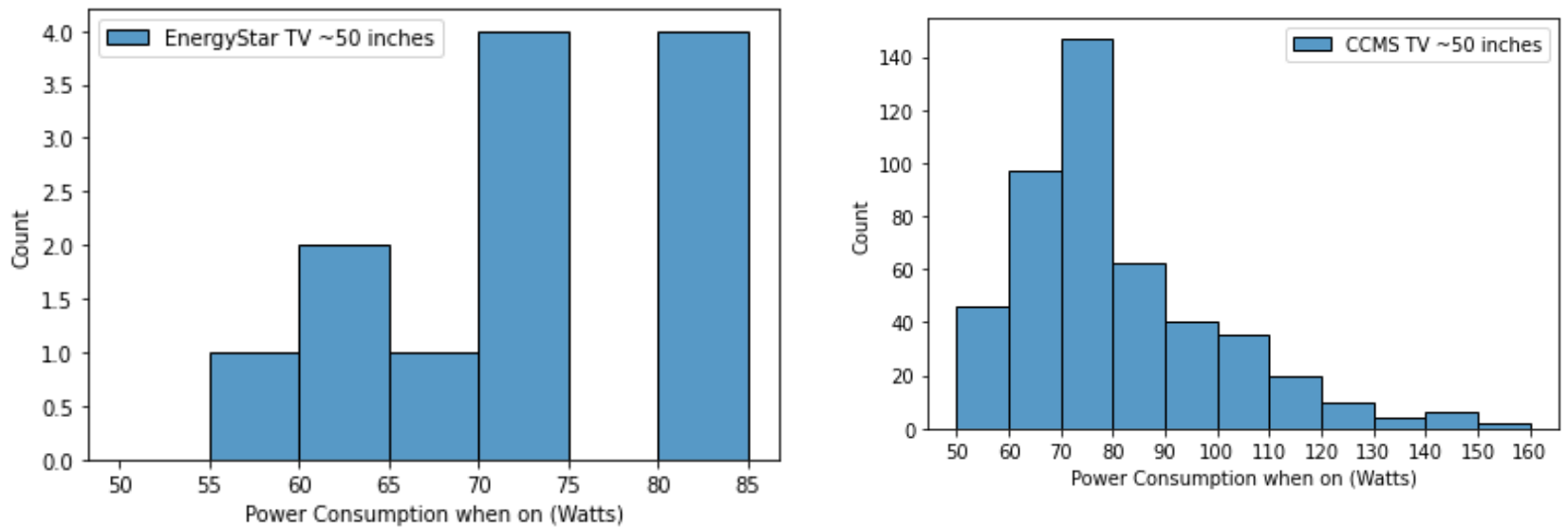

Figure S10: Histogram of counts of 50-inch televisions as a function of electronic power ratings

\section{Refrigerators}

The CCMS and Energy Star databases list the estimated the annual energy use of refrigeratorfreezer units, and compact and stand-alone refrigerator or freezers. The build configuration, volume, and additional features such as icemakers can influence the annual energy use. For the systems analysis, non-compact refrigerator-freezer combination units were considered to identify the range of power consumption of household refrigeration.
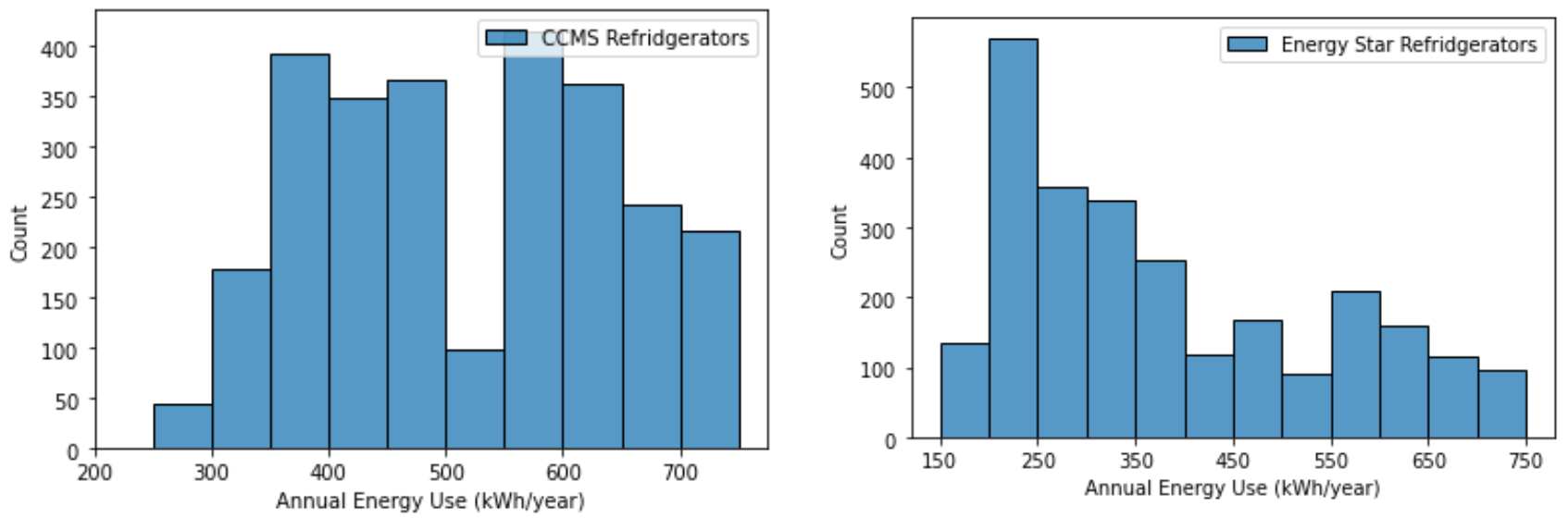

Figure S11: Histograms of counts of full-sized household refrigerator-freezers as a function of annual power consumption ratings

\section{Dishwashers}

Dishwasher efficiency is gauged on the annual energy consumption of typical household use of the appliance. The typical dishwasher operation is assumed to be 215 loads per year, or around 4 per week, as referenced by the U.S. Department of Energy test procedure, Code of Federal Regulations, Title 10, Section 430, Subpart B, Appendix C. Dishwashers are typically plumbed with hot water only and have additional heating elements to raise the water temperature to enhance performance. The NSF/ANSI Standard 184 requires a dishwasher to reach $150{ }^{\circ} \mathrm{F}$ for a sanitation cycle which must reach a 5-log reduction in bacteria. This additional heating contributes to the dishwasher energy use. The water efficiency is also measured by the DOE and 
Energy Star, rated by the gallons used per cycle. All households do not have a dishwasher, so a handwash only scenario is also considered. The USGS estimates a per capita water use of 9-27 gallons per cycle when washing by hand, for the systems analysis 16 gallons per cycle was chosen for the handwash only scenario.
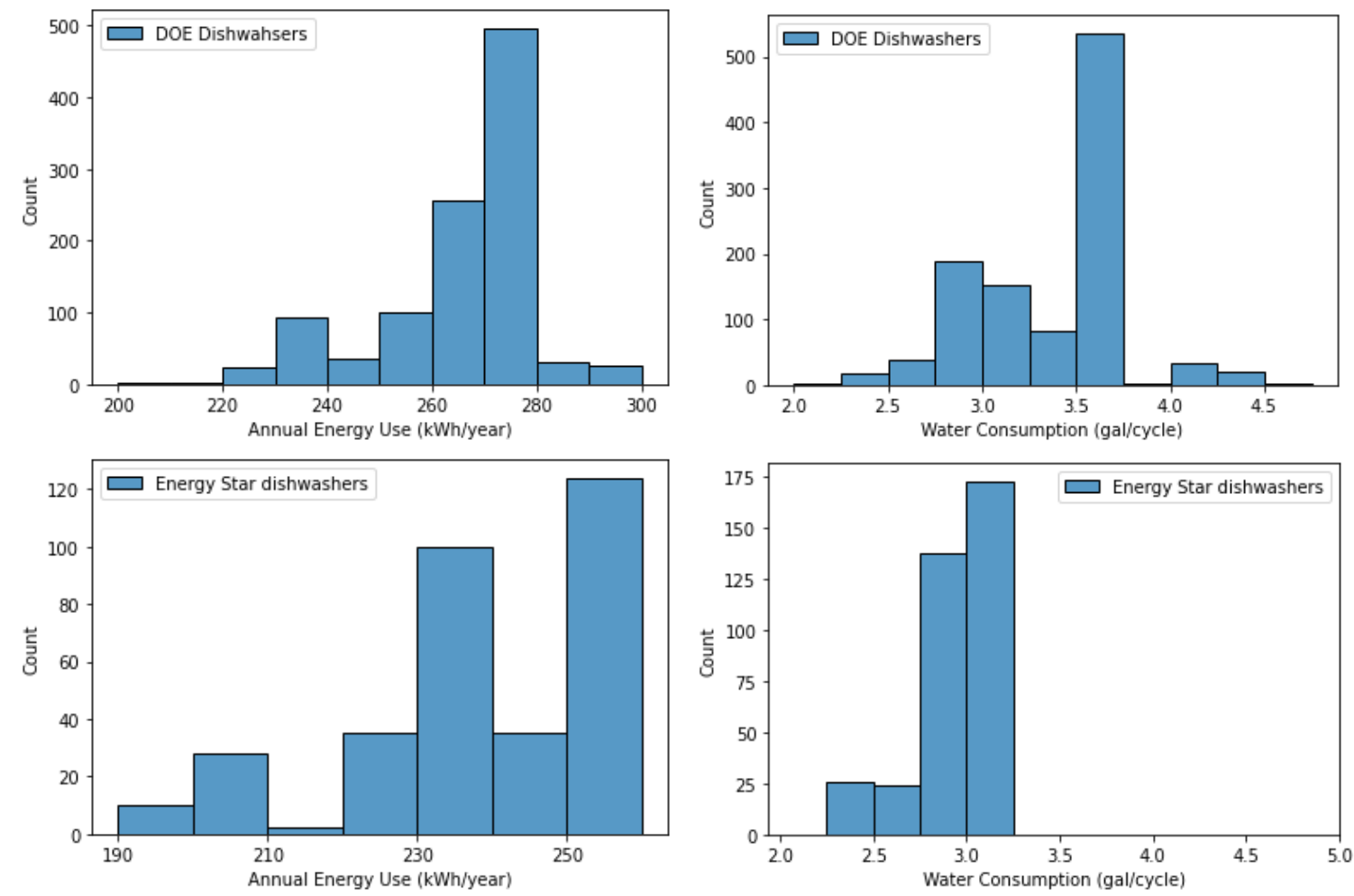

Figure S12: Histograms of counts of dishwashers as a function of annual energy use and water consumption

\section{Showerheads and Faucets}
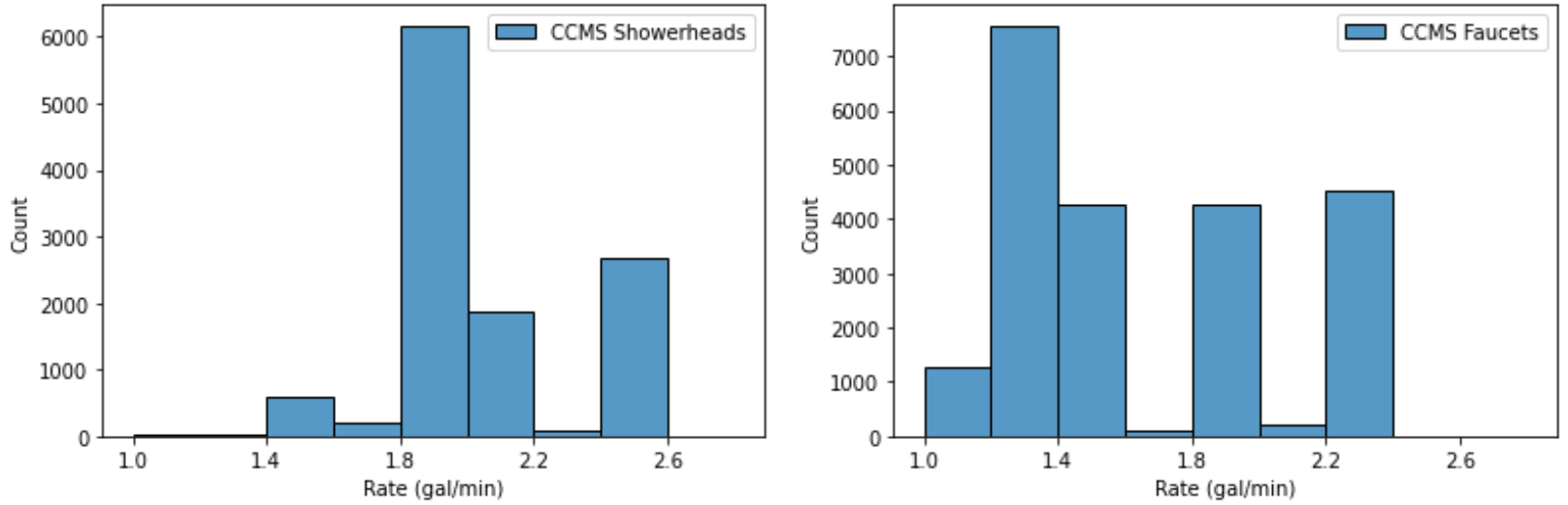

Figure S13: Histograms of counts of showerheads and faucets with respect to the flow rate, gallons per minute. 
Text S4: Modular indoor graywater collection and treatment systems

We considered following commercially available modular graywater collection and treatment units to quantify the recycled graywater with medium- and high-efficiency units.

Sloan AQUS HMA7000 Water Reuse System ${ }^{52}$ :

- Unit price: 400 USD

- Storage volume: 20 liters/5.5 gallons

- Treatment type: Chemical disinfection, filtration

- Treatment capacity: 34-56 liters/9-15 gallons/day (lavatory faucet daily use)

- Uses: toilet flushing

Hydraloop $\mathrm{H}_{600}{ }^{53}$ :

- Unit price: 4,000 USD

- Storage volume: 600 Liters/160 gallons

- Treatment type: sedimentation, floatation, dissolved air flotation, foam fractionization, membrane bioreactor, UV-disinfection.

- Treatment capacity: 1,000 liters/260 gallons/day

- Uses: Toilet flushing, clothes washing, landscape irrigation

AQUALOOP AL-GW300 Packaged System ${ }^{54}$ :

- Unit price: 7,840 USD

- Storage volume: 300 liters/scalable with separate tank. Compatible 100 to 10,000 gallon tanks available

- Treatment type: ultrafiltration

- Treatment capacity: 300 liters/80 gallons/day

- Uses: Toilet flushing, clothes washing, landscape irrigation and spray irrigation, potable water

Table S2: Literature review on $\mathrm{N}$ and $\mathrm{P}$ recovery from blackwater.

\begin{tabular}{|c|c|c|c|c|}
\hline & $\begin{array}{l}\text { Urine nutrient } \\
\text { production }\end{array}$ & $\begin{array}{l}\text { Feces nutrient } \\
\text { production }\end{array}$ & $\begin{array}{l}\text { Non separated } \\
\text { nutrient production }\end{array}$ & Note \\
\hline $\begin{array}{l}\text { Jonsson et al } \\
2005^{55}\end{array}$ & $\begin{array}{l}5.1-11 \mathrm{~g} \mathrm{~N} / \mathrm{cap} / \mathrm{d} \\
0.41-1 \mathrm{~g} \mathrm{P} / \mathrm{cap} / \mathrm{d}\end{array}$ & $\begin{array}{l}1.5-1.95 \mathrm{~g} \mathrm{~N} / \mathrm{cap} / \mathrm{d} \\
0.5-0.69 \mathrm{~g} \mathrm{P} / \mathrm{cap} / \mathrm{d}\end{array}$ & & \\
\hline Rose et al $2015^{56}$ & $\begin{array}{l}2-35 \mathrm{~g} \mathrm{~N} / \mathrm{cap} / \mathrm{d} \\
0.45-2.5 \mathrm{~g} \\
\mathrm{P} / \text { cap/day } \\
61 \mathrm{~g} \text { urine/cap/day }\end{array}$ & 32 g stool/cap/day & & \\
\hline $\begin{array}{l}\text { Verstraete et al } \\
2009^{57}\end{array}$ & & & $\begin{array}{l}4.75 \mathrm{~g} \mathrm{~N} / \mathrm{cap} / \mathrm{d} \\
2 \mathrm{~g} \mathrm{P} / \text { cap } / \mathrm{d} \\
1 \mathrm{~g} \text { struvite } / 1 \mathrm{~m} 3 \\
0.05 \mathrm{~kg} \mathrm{~N} / \mathrm{m} 3 \\
\end{array}$ & $\begin{array}{l}\text { Current decentralized } \\
\text { activated sludge } \\
\text { Nitrification } \\
\text { Chemical extraction of P }\end{array}$ \\
\hline \multicolumn{5}{|c|}{ Source separation and nutrient potential } \\
\hline $\begin{array}{l}\text { Vinneras et al } \\
2001^{58}\end{array}$ & $\begin{array}{l}3741 \text { g N/cap/year } \\
340 \text { g P/cap/pear }\end{array}$ & $\begin{array}{l}632 \mathrm{~g} \mathrm{~N} / \mathrm{cap} / \text { year } \\
126 \mathrm{~g} \mathrm{P} / \mathrm{cap} / \text { year }\end{array}$ & & $\begin{array}{l}\text { Urine diverting toilets } \\
\text { Urine collection and testing } \\
\text { Feces collection and testing }\end{array}$ \\
\hline
\end{tabular}




\section{Text S5: Rainwater harvesting unit}

A rainwater collection system was referenced to a system according to the Luling Foundation Farm. The system can collect approximately 550 gallons of rainwater for every 1,000 square feet of collection surface per inch of rain ${ }^{59}$.

\section{Text S6: Trade-off between household expenditures and system energy and water efficiency}

The NREL database ${ }^{60}$ was referenced for cost data on clothes dryers, clothes washers, cooking ranges, dishwashers, refrigerators, air conditioners, air-source heat pumps, water heaters, and furnaces. A systems analysis tool was configured using the Excel solver to generate Pareto optimal solutions (i.e., combinations of discrete appliance and fixture options) with respect to household system emissions, water use, and capital cost. The tool also computes total annualized costs, based on annual utility cost, product lifetimes, and a discount rate input by the user; however, tradeoffs were not observed with respect to water use and emissions since the higher efficiently options are also more cost-effective over their lifetimes. With minor edits, the user can perform the multi-objective optimization using either the weighting method or e-constraint method $^{61}$. For example, the model can be set up to minimize total capital cost with constraints on water use and emissions; or, alternatively, the model can minimize a weighted sum of emissions and water use subject to a constraint on investment cost.

Capital cost was calculated as the summation of purchase and installation cost for the products in the system configuration in relation to product efficiency. The associated capital costs are listed in Table S3. The annualized cost is the summation of capital cost projected over the product's estimated lifespan, the associated unit utility rates times annual use generated from the model, and associated maintenance costs. The average residential unit utility rates in the U.S. for water/sewage ( $\$ / 1,000$ gallons), residential electricity $(\$ / \mathrm{kWh})$, and residential gas $(\$ /$ therm) were adapted from the Savings Calculator for Energy Star qualified appliances excel spreadsheet $^{62}$.

Table S3: Capital cost of household appliances for baseline, medium-efficiency, and highefficiency.

\begin{tabular}{lccc} 
System product & Baseline & $\begin{array}{c}\text { Medium } \\
\text { Efficiency }\end{array}$ & $\begin{array}{c}\text { High } \\
\text { Efficiency }\end{array}$ \\
\hline \hline Electric Furnace $^{60}$ & $\$ 1,600$ & $\$ 1,600$ & $\$ 1,600$ \\
Air Source Heat Pump $^{60}$ & $\$ 3,400$ & $\$ 4,000$ & $\$ 4,600$ \\
Gas Furnace $^{60}$ & $\$ 1,900$ & $\$ 2,100$ & $\$ 2,500$ \\
Central Air Conditioning Unit $^{60}$ & $\$ 2,200$ & $\$ 2,500$ & $\$ 3,000$ \\
Water Heater (Gas Storage) $^{60}$ & $\$ 850$ & $\$ 950$ & $\$ 1,025$ \\
$\begin{array}{l}\text { Water Heater (Electric Storage/hybrid heat pump) } \\
60\end{array}$ & $\$ 750$ & $\$ 1,660$ & $\$ 2,828$ \\
Light Bulbs $^{\mathrm{a}}$ & $\$ 50$ & $\$ 96$ & $\$ 100$ \\
Cloths Dryer (gas) $^{60}$ & $\$ 1,000$ & $\$ 1,000$ & $\$ 1,000$ \\
Cloths Dryer (electric) $^{60}$ & $\$ 500$ & $\$ 760$ & $\$ 1,300$ \\
Refrigerator $^{60}$ & $\$ 1,000$ & $\$ 1,300$ & $\$ 1,400$ \\
Cooking Range (gas) $^{60}$ & $\$ 820$ & $\$ 820$ & $\$ 820$ \\
\hline
\end{tabular}




\begin{tabular}{|c|c|c|c|}
\hline Cooking Range (electric) ${ }^{60}$ & $\$ 920$ & $\$ 920$ & $\$ 920$ \\
\hline Cloths Washer ${ }^{60}$ & $\$ 560$ & $\$ 880$ & $\$ 1,400$ \\
\hline Dishwasher $^{60}$ & $\$ 750$ & $\$ 780$ & $\$ 810$ \\
\hline Toilet $^{\mathrm{a}}$ & $\$ 50$ & $\$ 115$ & $\$ 170$ \\
\hline Irrigation System ${ }^{63}$ & $\$ 2,180$ & $\$ 2,537$ & $\$ 3,270$ \\
\hline Graywater Reuse System $52,53,54$ & $\$ 800$ & $\$ 4,000$ & $\$ 7,840$ \\
\hline Shower Heada & $\$ 12$ & $\$ 15$ & $\$ 20$ \\
\hline Faucet $^{\mathrm{a}}$ & $\$ 12$ & $\$ 15$ & $\$ 20$ \\
\hline $50^{\prime \prime} \mathrm{TV}^{\mathrm{a}}$ & $\$ 200$ & $\$ 300$ & $\$ 400$ \\
\hline Desktop Computer ${ }^{\mathrm{a}}$ & $\$ 100$ & $\$ 500$ & $\$ 1,000$ \\
\hline Laptop Computer ${ }^{\mathrm{a}}$ & $\$ 100$ & $\$ 500$ & $\$ 1,000$ \\
\hline
\end{tabular}

a. Cost estimated by reviewing current marketplace prices online in 2021

Results presented herein were derived using an objective function that maximizes a sum reduction of normalized water use and emissions relative to a reference benchmark. For each scenario, the total household water use and emissions were first normalized relative to the baseline natural gas scenario (Table SI-1):

$$
\begin{aligned}
& W=\frac{\text { Water Consumption }}{\text { Baseline Water Consumption }} \\
& E=\frac{\text { Emissions }}{\text { Baseline Emissions }}
\end{aligned}
$$

In the model, the appliances choices were represented as binary (0-1) variables, $Y_{i j}$, and constraints were added to ensure one and only one appliance is selected for each household purpose (e.g., space heating, space cooling, water heating). The total investment cost, water use, and emissions under each scenario were then calculated as simple (linear) summations:

$X=\sum_{j} \sum_{i} c_{i j} Y_{i j}, W=\sum_{j} \sum_{i} w_{i j} Y_{i j}$, and $E=\sum_{j} \sum_{i} e_{i j} Y_{i j}$

where $c_{i j}$ is the investment cost, $w_{i j}$ is the water use, and $e_{i j}$ is the emissions corresponding to technology choice $i$ for the household appliance $j$.

Annualized investment cost (AIC) is for each appliance is computed as follows:

$A I C_{i j}=\frac{r \times c_{i j}}{1-(1+r)^{-n}}$

where $r$ is the annual discount rate and $n$ is the lifetime of the appliance. The total annual cost is the summation of the annualized investment cost, annual energy cost, and annual maintenance cost. A discount rate of $5 \%$ was used in the calculations, along with the estimated lifetime of each appliance (values provided in the spreadsheet). 
Table S4: Capital and annualized costs, $\mathrm{CO}_{2} \mathrm{e}$ emissions, and water use of the benchmark configuration (i.e., the use of natural gas) and the use of total electricity with baseline, mediumefficiency, and high-efficiency appliances, and those obtained by the six optimization steps.

\begin{tabular}{|c|c|c|c|c|c|c|c|c|c|c|c|c|c|}
\hline & & $\begin{array}{l}\text { Capital Cost } \\
\end{array}$ & GHG emissions & Water Consumption & Annualized cost & Cost $(x)$ & Emissions (E) & Water use $(\mathrm{W})$ & $\mathrm{E}(\mathrm{x})$ & $\mathrm{W}(\mathrm{x})$ & Emission $\mathrm{OF}$ & Water $\mathrm{OF}$ & Objective value \\
\hline \multirow{3}{*}{$\begin{array}{l}\text { Natural } \\
\text { gas }\end{array}$} & $\begin{array}{c}\text { Baseline } \\
\end{array}$ & $=811,879.99$ & $\begin{array}{ll}10,947 \\
\end{array}$ & $\begin{array}{ll}388.47 \\
\end{array}$ & $\begin{array}{l}4610.48 \\
\end{array}$ & 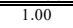 & $\overline{c 1.00}$ & $\overline{c 1.00}$ & 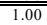 & $\overline{c 1.00}$ & 0.00 & 0.00 & 0.01 \\
\hline & Medium & $\$ 13,632.99$ & 8,218 & 275.01 & 3786.00 & 1.15 & 0.75 & 0.71 & 0.83 & 0.78 & 0.07 & 0.07 & 0.15 \\
\hline & High & $\$ 15,994.99$ & 6,842 & 203.13 & 3493.59 & 1.35 & 0.63 & 0.52 & 0.59 & 0.48 & -0.04 & -0.04 & -0.08 \\
\hline \multirow{3}{*}{$\begin{array}{l}\text { Total } \\
\text { electricity }\end{array}$} & Baseline & $\$ 14,479.99$ & 11,290 & 388.47 & 6015.33 & 1.22 & 1.03 & 1.00 & 0.74 & 0.67 & -0.29 & -0.33 & -0.62 \\
\hline & Medium & $\$ 17,667.99$ & 8,378 & 275.01 & 5104.62 & 1.49 & 0.77 & 0.71 & 0.42 & 0.27 & -0.35 & -0.44 & -0.79 \\
\hline & High & $\$ 21,917.99$ & 7,245 & 203.13 & 4910.40 & 1.84 & 0.66 & 0.52 & -0.02 & -0.27 & -0.68 & -0.79 & -1.47 \\
\hline \multirow{6}{*}{ Optimization } & 1 & $\$ 11,279.99$ & 10,972 & 388.47 & 4847.84 & 0.95 & 1.00 & 1.00 & 1.06 & 1.08 & 0.06 & 0.08 & 0.14 \\
\hline & 2 & $\$ 11,609.99$ & 8,769 & 273.19 & $4,077.29$ & 0.98 & 0.80 & 0.70 & 1.03 & 1.04 & 0.23 & 0.34 & 0.56 \\
\hline & 3 & $\$ 12,022.99$ & 8,777 & 258.10 & 3852.70 & 1.01 & 0.80 & 0.66 & 0.99 & 0.99 & 0.19 & 0.32 & 0.51 \\
\hline & 4 & $\$ 13,441.99$ & 7,337 & 233.34 & 3698.16 & 1.13 & 0.67 & 0.60 & 0.84 & 0.81 & 0.17 & 0.21 & 0.38 \\
\hline & 5 & $\$ 13,941.99$ & 7,083 & 233.34 & 3659.50 & 1.17 & 0.65 & 0.60 & 0.79 & 0.74 & 0.15 & 0.14 & 0.29 \\
\hline & 6 & $\$ 15,074.99$ & 6,888 & 208.26 & 3606.85 & 1.27 & 0.63 & 0.54 & 0.68 & 0.60 & 0.05 & 0.06 & 0.11 \\
\hline
\end{tabular}

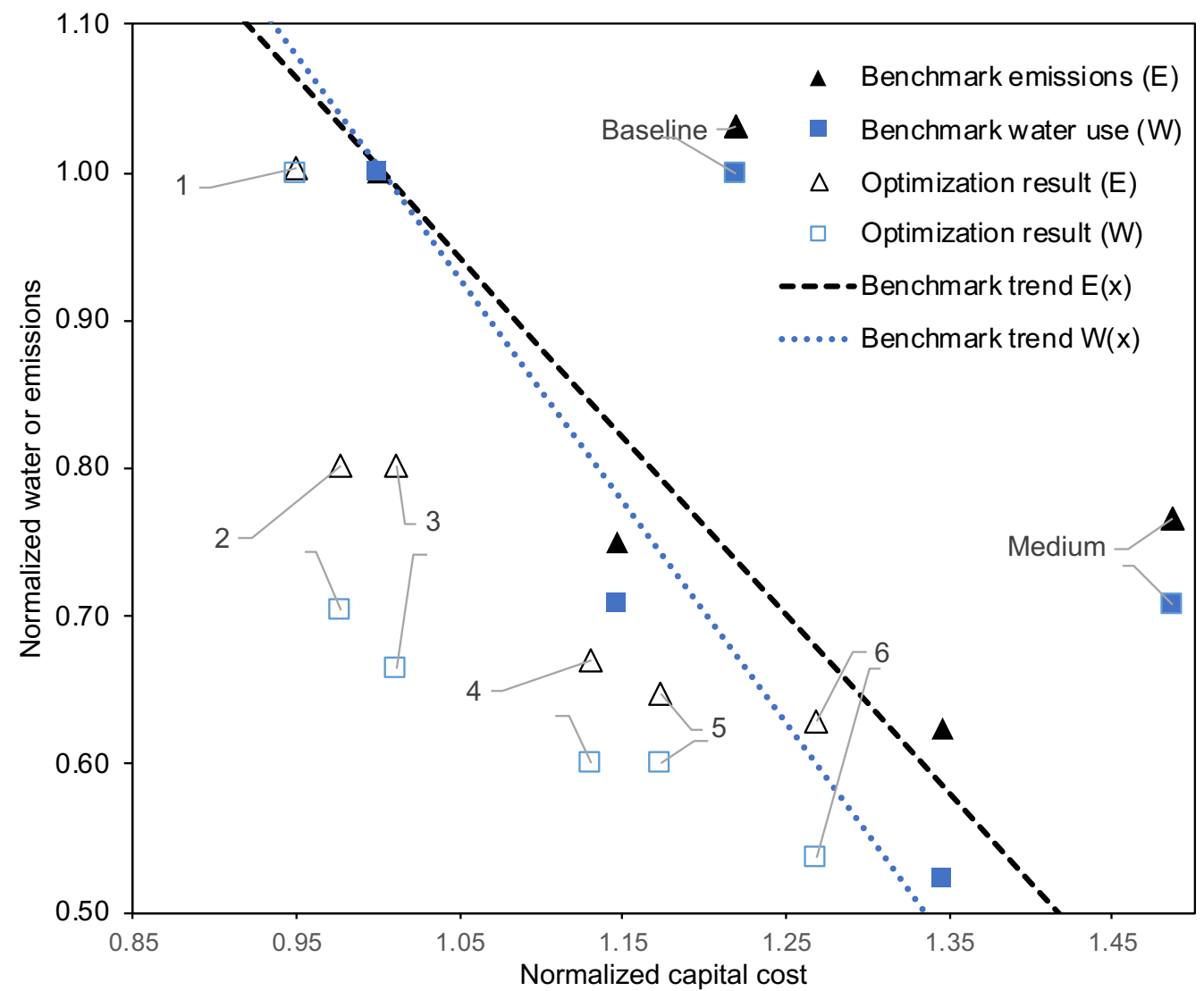

Figure S14: Plot of normalized emission (E(x) value) and water (W(x) value) as a function of normalized capital cost ( $\mathrm{x}$ value) in equation (1) 


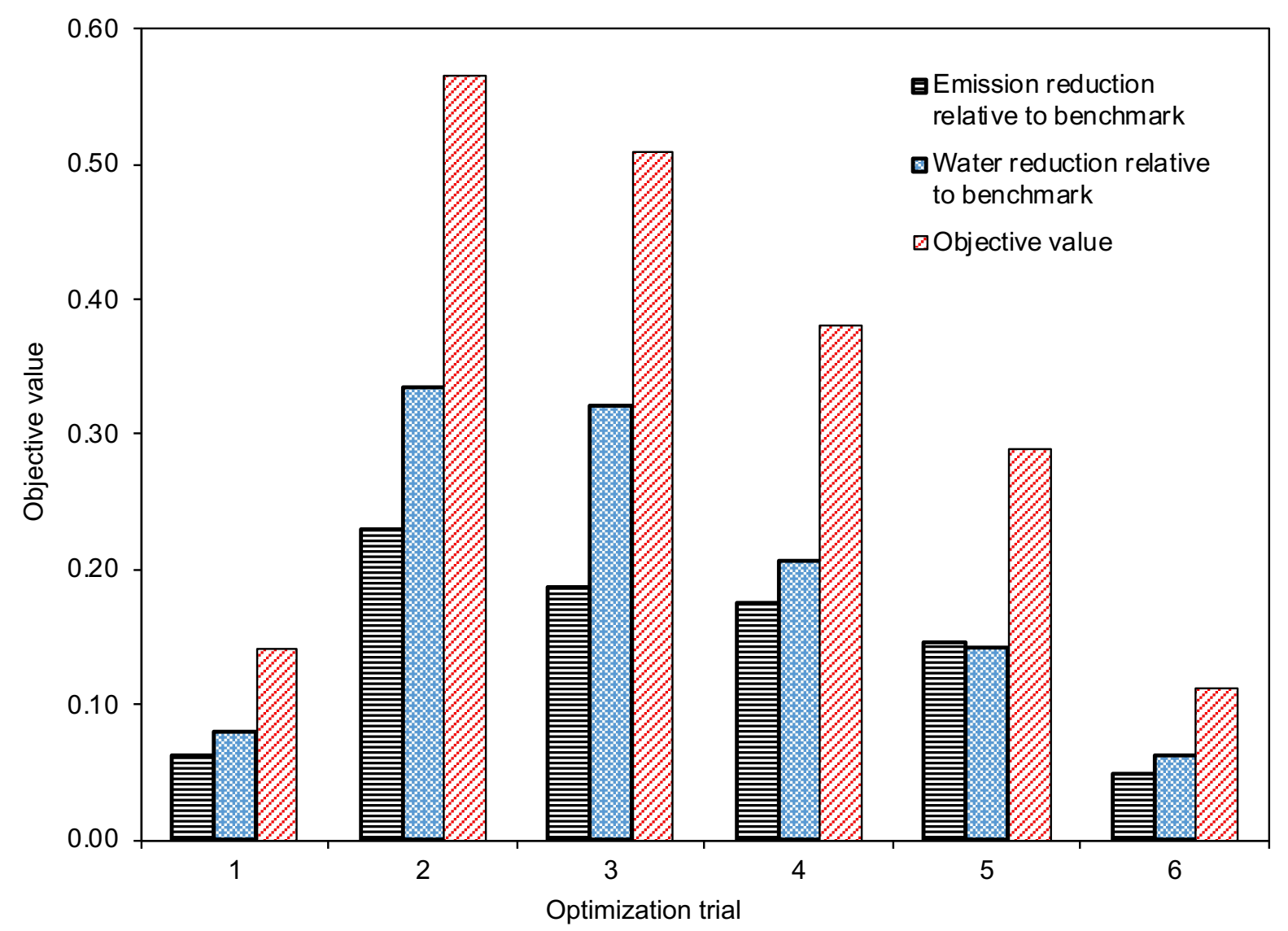

Figure S15: Evolution of objective function values at each step of optimization from overall optimization, and the relative contribution from emissions and water consumption to the benchmark scenario. 
Table S5: List of appliance efficiency choices from overall optimization, emissions-only optimization, and water consumption-only optimization.

\begin{tabular}{|c|c|c|c|}
\hline $\begin{array}{l}\text { Household } \\
\text { system }\end{array}$ & $\begin{array}{l}\text { List of choices from } \\
\text { overall optimization }\end{array}$ & $\begin{array}{l}\text { List of choices from } \\
\text { maximizing the } \\
\text { emission only }\end{array}$ & $\begin{array}{l}\text { List of choices from } \\
\text { maximizing water only }\end{array}$ \\
\hline $\begin{array}{l}\text { Space heater } \\
\text { furnace }\end{array}$ & Baseline natural gas & Baseline natural gas & Electric coil furnace \\
\hline Space cooler & Baseline & Medium Efficiency & Baseline \\
\hline Water heater & $\begin{array}{l}\text { Baseline electric } \\
\text { storage }\end{array}$ & $\begin{array}{l}\text { High Efficiency gas } \\
\text { storage }\end{array}$ & Baseline electric storage \\
\hline Lighting & LED & LED & Incandescent \\
\hline Clothes dryer & Baseline electric & Baseline electric & Baseline electric \\
\hline Clothes washer & Baseline & Baseline & Baseline \\
\hline Electronics & High Efficiency & High Efficiency & Baseline \\
\hline Refrigerator & Baseline & Baseline & Baseline \\
\hline Dishwasher & High Efficiency & Handwash Only & Baseline \\
\hline Cooking range & Electric & Electric) & Electric \\
\hline Showerhead & High Efficiency & High Efficiency & High Efficiency \\
\hline Faucet & High Efficiency & High Efficiency & High Efficiency \\
\hline Toilet & High Efficiency & High Efficiency & High Efficiency \\
\hline $\begin{array}{l}\text { Landscape } \\
\text { irrigation system }\end{array}$ & Baseline & Baseline & Baseline \\
\hline
\end{tabular}

\section{Text S7: Sensitivity analysis to climate variation and limitation of the input-output model}

A sensitivity analysis was performed to test the model sensitivity to climate variation. The most significant system contribution to household emissions is from space heating and cooling which incorporate heating degree days and cooling degree days to estimate the energy consumption and associated emissions. The climate data used in the model was representative of the northern Illinois region as a testbed. For comparison, climate data from Texas gathered from NOAA climate normals ${ }^{64}$ was input into the model. Figure S15 compares the trade-off curves of $\mathrm{CO}_{2} \mathrm{e}$ emissions with respect to the annualized and capital cost for the baseline natural gas, total electricity, and optimized scenarios. The results show a slight decrease in emissions using Texas climate data. Due to the alternative inputs of heating and cooling degree days, a much lower heating requirement reduces the overall emissions despite the increased cooling requirement. The relative relationship between cost and efficiency remained unchanged, and water use was not affected.

Our model calculated a lower GHG emission for Texas relative to the estimate for Illinois when testing only the variation in heating and cooling degree days between the regions. The energy and emissions calculated for heating and cooling were delt with differently in the model; heating estimates were based on the estimated energy requirement of a household per heating degree days and household size and was dominated by combustion-fueled furnaces, and the cooling estimates were based on the predicted running time of the air conditioning unit which were predominantly air-source heat pump systems which required electrical energy. The reason the model calculates less energy input per hour of useful cooling than heating is due to the SEER rating for air conditioning systems. The heat content of electricity is approximately $3.41 \mathrm{Btu} / \mathrm{W}-$ $\mathrm{hr}$, while the cooling content of electricity for heat pump systems reported in Btu/W-hr is 
indicated by the system's seasonal energy efficiency ratio, or SEER rating. The SEER rating of air conditioning units and air-source heat pump systems reported in the CCMS database range from 13 SEER to 24 SEER (Btu/W-h). Because the SEER values are relatively high for current heat pump technology, the Btu/hour capacity of a heat pump system can remove heat energy more efficiently than conventional heating can add heat energy. The blackouts and enormous energy demand of cooling in Texas may be attributed to the fact that cooling predominantly relies on electricity, while heating predominantly relies on primary fuels such as natural gas which means the supply and demand flux for heating in cold climates does not stress the electric power sector. Other regional variables such as household size and the balance of supply and demand were not analyzed for this analysis.
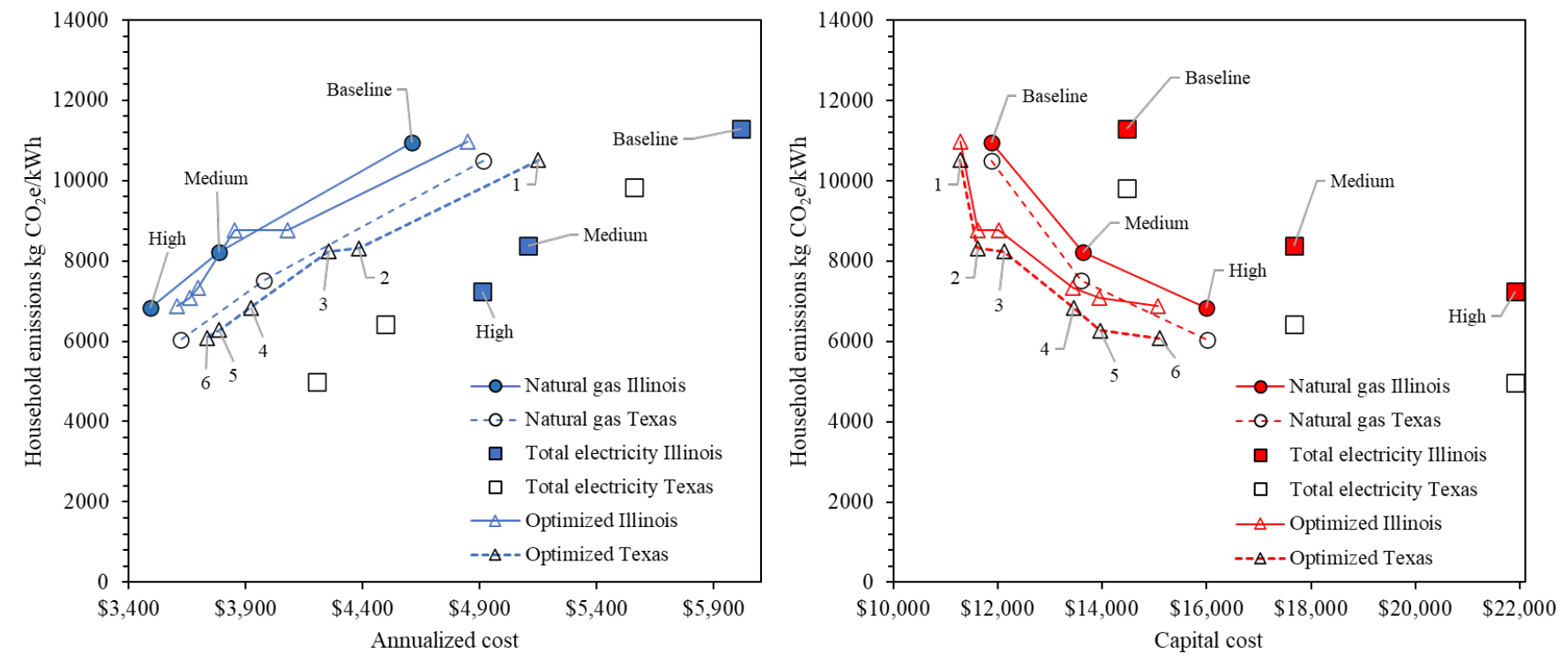

Figure S16: Sensitivity analysis comparing the trade-off curves of $\mathrm{CO}_{2} \mathrm{e}$ emissions with respect to annualized and capital cost of the scenarios and optimizations using Illinois climate data and Texas climate data.

The goal of the systems analysis was to estimate the relative impact of changes in electric power emissions, system efficiency, and primary fuel source. The typical household is composed of many additional products and systems that may not be represented. Furthermore, regional behavior and income-related behavior are major factors that influence typical household emissions ${ }^{32}$ which were not analyzed here.

While optimized household system configurations as a function of capital cost were identified, little to no optimization was observed relative to the annualized cost. A trade-off analysis which includes reductions via typical use behavior, potential rebound effects, and their relative impacts compared to upgrades in appliance efficiency could add an additional dimension in further analysis.

The Excel-based solver algorithm also presents some limitations of compatibility with the systems model. It was observed that local optimum solutions for the objective function could satisfy the solver when all constraints were satisfied. Factors that may contribute to this limitation include the non-smooth incremental relationship of cost, water use, emissions, and efficiency in the model. This could arise from uneven increments of cost and efficiency metrics between levels of efficiency that were chosen based on available product data rather than a 
mathematical trend. Additional non-smooth incremental changes are present due to the different equations used to estimate natural gas and electric appliance emissions which are embedded in the same system categories. Such limitations can be partially mitigated by varying the constraints on cost, $\mathrm{CO}_{2} \mathrm{e}$ emissions, and/or water use causing the solver to find new solutions. The finite number of available configurations also allow the user to manually test the solution and alter the starting configuration from which to optimize.

To fully test the capability of the Excel-based solver algorithm, three sets of trials were run to produce Pareto optimal solutions to minimize household water use and emissions subject to varying levels of a constraint on capital cost. The first two sets of trials omit the influence of hot water use from other water consuming systems, such as showerhead and faucet efficiency, by assuming the median value of hot water use for water heating. This assumption allows solution using Excel's Simplex LP solver, which guarantees global optimal solutions for this linearized version of the model. Trials 1-9 use the Simplex solver to find Pareto optimal solutions for various formulations of the objective function and capital cost constraint, and Trials 10-18 use the Evolutionary solver for the same set of model formulations. Table S6 summarizes the optimization trials. Although the Evolutionary solver does not guarantee global optimal solutions, the results of these trials illustrate that it finds the global optimal solution (i.e., matching the Simplex LP solution) with a high degree of reliability.

Table S6: Summary of linear optimization trials used to test the Excel Evolutionary solver against the Simplex LP solver.

\begin{tabular}{|c|c|c|c|c|}
\hline $\begin{array}{l}\text { Simplex } \\
\text { LP } \\
\text { Solver } \\
\end{array}$ & $\begin{array}{l}\text { Evolutionary } \\
\text { Solver }\end{array}$ & $\begin{array}{c}\text { Pareto } \\
\text { Optimization }\end{array}$ & Constraint & Constraint notes \\
\hline 1 & 10 & $\begin{array}{l}\text { minimize } x \\
\text { maximize } W \text { and } E\end{array}$ & $\begin{array}{c}\text { No } \\
\text { constraint } \\
\text { No }\end{array}$ & No cost constraint \\
\hline 2 & 11 & reduction & $\begin{array}{l}\text { constraint } \\
\text { Cost }(x)\end{array}$ & $\begin{array}{c}\text { No cost constraint } \\
\text { At or below baseline benchmark }\end{array}$ \\
\hline 3 & 12 & minimize $\mathrm{W}$ & $\begin{array}{c}\leq 1.00 \\
\operatorname{Cost}(\mathrm{x})\end{array}$ & $\begin{array}{c}\text { cost } \\
\text { At or below baseline benchmark }\end{array}$ \\
\hline 4 & 13 & minimize $\mathrm{E}$ & $\begin{array}{c}\leq 1.00 \\
\operatorname{Cost}(\mathrm{x})\end{array}$ & $\begin{array}{c}\text { cost } \\
\text { At or below medium efficiency }\end{array}$ \\
\hline 5 & 14 & minimize $\mathrm{W}$ & $\begin{array}{l}\leq 1.15 \\
\operatorname{Cost}(\mathrm{x})\end{array}$ & $\begin{array}{l}\text { benchmark cost } \\
\text { At or below medium efficiency }\end{array}$ \\
\hline 6 & 15 & minimize $\mathrm{E}$ & $\begin{array}{c}\leq 1.15 \\
\operatorname{Cost}(\mathrm{x})\end{array}$ & $\begin{array}{c}\text { benchmark cost } \\
\text { At or below high efficiency }\end{array}$ \\
\hline 7 & 16 & minimize $\mathrm{E}$ & $\begin{array}{c}\leq 1.35 \\
\operatorname{Cost}(\mathrm{x})\end{array}$ & $\begin{array}{l}\text { benchmark cost } \\
\text { At or below high efficiency }\end{array}$ \\
\hline 8 & 17 & minimize $\mathrm{E}+\mathrm{W}$ & $\begin{array}{c}\leq 1.35 \\
\text { No }\end{array}$ & benchmark cost \\
\hline 9 & 18 & minimize $\mathrm{E}$ & constraint & No cost constraint \\
\hline
\end{tabular}

The third set of trials (19-27) represents the home water-energy system more accurately by allowing both the hot water use and the water heater efficiency to impact the water heater energy use variable. These results in a non-linear relationship between household systems efficiencies and system emissions output; therefore, only the Evolutionary solver was used. 
Figure S17 plots the results from Trials 1-9 along with trials 19-27, illustrating the differences between the linear and nonlinear model formulations. In the nonlinear case, choices that minimize hot water use are more favorable since these represent lower cost options than most appliance energy efficiency upgrades.

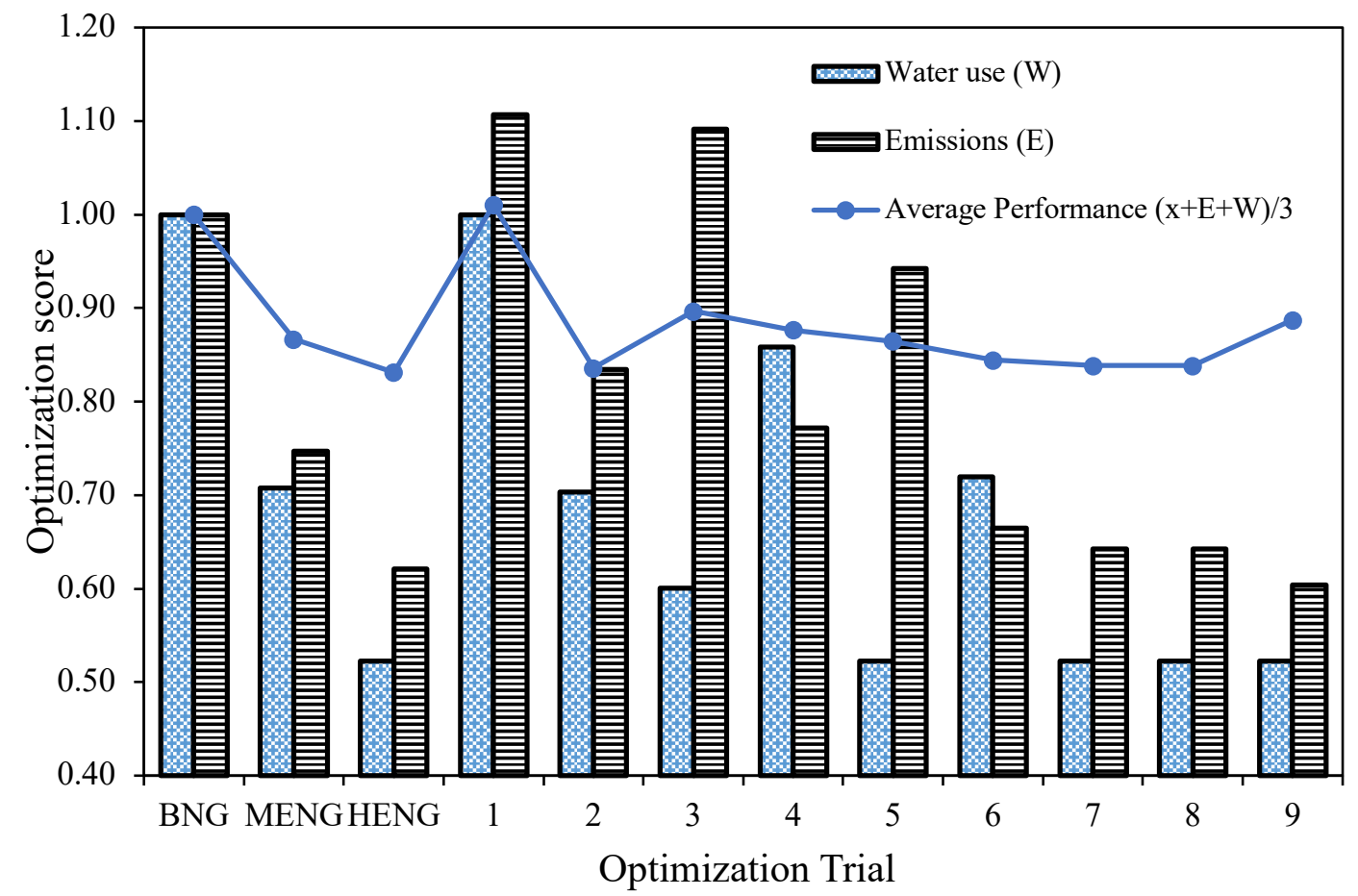

Figure S17: Optimization score obtained from the optimization trials 1-9.

\section{References}

${ }^{1}$ PJM Data miner 2. Generation by Fuel Type. https://dataminer2.pjm.com/feed/gen_by_fuel/definition accessed on June 28, 2021.

2 EIA. Monthly Energy Review (MER). DOE/EIA-0035(2018/4), U.S. Energy Information Administration, Jan. 2020, p. 272, www.eia.gov/mer.

${ }^{3}$ EPA, OAR. "(EGRID) Comprehensive Source of Data." US EPA, 20 Aug. 2020, https://www.epa.gov/egrid/download-data.

${ }^{4}$ Warner, E.; Heath, G.; O’Donoughue, P. Harmonization of Energy Generation Life Cycle Assessments (LCA): FY2010 LCA Milestone Report, November 2010. Renewable Energy 2010, 17.

${ }^{5}$ Garvin Heath. "Life Cycle Assessment Harmonization of electricity generation technologies." NREL.Gov, https://www.nrel.gov/analysis/life-cycle-assessment.html. Accessed 29 Apr. 2021.

${ }^{6}$ Intergovernmental Panel on Climate Change. SRREN Report; 2011. 
${ }^{7}$ EIA. Annual Energy Outlook 2021. Independent Statistics \& Analysis, AEO 2021, 3 Feb. 2021, https://www.eia.gov/outlooks/aeo/data/browser/. Accessed on June 28, 2021.

${ }^{8}$ EPA, OAR. “(EGRID) Comprehensive Source of Data.” US EPA, 20 Aug. 2020, https://www.epa.gov/egrid/download-data.

${ }^{9}$ Whitaker, M.; Heath, G.A.; O'Donoughue, P.; Vorum, M. Life cycle greenhouse gas emissions of coal-fired electricity generation. J. Industrial Ecology. 2012, S53-S72.

${ }^{10}$ Heath, G.A.; O’Donoughue, P.; Arent, D.J.; Bazilian, M. Harmonization of initial estimates of shale gas life cycle greenhouse gas emissions for electric power generation. PNAS., 2014, E3167-E3176.

${ }^{11}$ Garvin Heath. "Life Cycle Assessment Harmonization of electricity generation technologies." NREL.Gov. Emission factors data resources. 2021.

${ }^{12}$ Warner, E.S.; Heath, G.A. Life cycle greenhouse gas emissions of nuclear electricity generation. J. Industrial Ecology. 2012, 16, S73-S92.

${ }^{13}$ EPRI. Literature review and sensitivity analysis of biopower life-cycle assessments and greenhouse gas emission. 2013.

${ }^{14}$ Eberle, A.; Heath, G.; Nicholson, S.; Carpenter, A. Systematic review of life cycle greenhouse gas emissions from geothermal electricity. National Renewable Energy Laboratory. Technical Report. NREL/TP-6A20-68474. 2017.

${ }^{15}$ Kim, H.C.; Fthenakis, V.; Choi, J-K.; Turney, D.E. Life cycle greenhouse gas emissions of thin-film photovoltaic electricity generation. J. Industrial Ecology. 2012, 16, S110-S121.

${ }^{16}$ Dolan, S.L.; Heath, G.A. Life cycle greenhouse gas emissions of utility-scale wind power. $J$. Industrial. Ecology. 2012, 16, S136-154.

${ }^{17}$ Kumar, A., T. Schei, A. Ahenkorah, R. Caceres Rodriguez, J.-M. Devernay, M. Freitas, D. Hall, Å. Killingtveit, Z. Liu, 2011: Hydropower. In IPCC Special Report on Renewable Energy Sources and Climate Change Mitigation [O. Edenhofer, R. Pichs-Madruga, Y. Sokona, K. Seyboth, P. Matschoss, S. Kadner, T. Zwickel, P. Eickemeier, G. Hansen, S. Schlömer, C. von Stechow (eds)], Cambridge University Press, Cambridge, United Kingdom and New York, NY, USA.

${ }^{18}$ The Engineering Toolbox. US Heating Degree-Days. 2009, https://www.engineeringtoolbox.com/us-degree-days-d_1569.html.

${ }^{19}$ Arguez, Anthony, et al. "NOAA's 1981-2010 U.S. Climate Normals: An Overview." Bulletin of the American Meteorological Society, vol. 93, no. 11, Nov. 2012, pp. 1687-97. DOI.org (Crossref), doi:10.1175/BAMS-D-11-00197.1. 
${ }^{20}$ U.S. EPA. Water Budget Tool. WaterSense New Home Specification. 2014.

21. Mark Fulton; Nils Mellquist; Saya Kitasei; Joel Bluestein. Comparing Life-Cycle Greenhouse Gas Emissions from Natural Gas and Coal; Worldwatch Institute, 2011.

${ }^{22}$ National Energy Technology Laboratory (NETL); Timothy J. Skone. Life Cycle Analysis of Natural Gas Extraction and Power Generation; DOE/NETL-2014/1646; Department of Energy, 2014

${ }^{23}$ Burnham, A.; Han, J.; Clark, C. E.; Wang, M.; Dunn, J. B.; Palou-Rivera, I. Life-Cycle Greenhouse Gas Emissions of Shale Gas, Natural Gas, Coal, and Petroleum. Environmental science \& technology 2012, 46 (2), 619-627.

${ }^{24}$ Heath, G.A.; O’Donoughue, P.; Arent, D.J.; Bazilian, M. Harmonization of initial estimates of shale gas life cycle greenhouse gas emissions for electric power generation. PNAS., 2014, E3167-E3176.

${ }^{25}$ U.S. Energy Information Administration (EIA) - Open Data - Natural Gas Gross Withdrawals and Production https://www.eia.gov/opendata/qb.php?category=457054 (accessed $2021-10-07$ ).

${ }^{26}$ Althaus, H.-J.; Doka, G.; Dones, R.; Heck, T.; Hellweg, S.; Hischier, R.; Nemecek, T.; Rebitzer, G.; Spielmann, M.; Wernet, G. Overview and Methodology Data v2.0; ecoinvent report No. 1; Swiss Centre for Life Cycle Inventories: Dübendorf, 2007.

${ }^{27}$ Energy units and calculators explained - U.S. Energy Information Administration (EIA) https://www.eia.gov/energyexplained/units-and-calculators/ (accessed 2021 -08 -17).

${ }^{28}$ Energy Information Administration (EIA). Carbon Dioxide Emissions Coefficients https://www.eia.gov/environment/emissions/co2_vol_mass.php (accessed 2021 -08 -17).

${ }^{29}$ Energy Information Administration. Monthly Energy Review (MER) Table A6; Independent Statistics \& Analysis DOE/EIA-0035(2018/4); 2020.

${ }^{30}$ United States Census Bureau. Average Size of Households in the U.S. 2020. Survey, Bureau of Labor Statistics, Nov. 2020, https://www.statista.com/statistics/183648/average-size-ofhouseholds-in-the-us/.

${ }^{31}$ EIA. Residential Energy Consumption Survey (RECS). 2015 RECS, Energy Information Administration (EIA), Oct. 2017, https://www.eia.gov/consumption/residential/data/2015/hc/php/hc10.11.php.

32 Goldstein, B.; Gounaridis, D.; Newell, J.P. The carbon footprint of household energy use in the United States. PNAS. 2020, 117(32), 19122-19130.

${ }^{33}$ EPA. ENERGY STAR Product Finder API \& Datasets | EPA ENERGY STAR. https://www.energystar.gov/productfinder/advanced. (accessed on April 5 ${ }^{\text {th }}, 2021$ ). 
${ }^{34}$ Energy Information Administration. Residential Energy Consumption Survey (RECS); 2015 RECS; Energy Information Administration (EIA), 2017.

${ }^{35}$ Department of Energy. Energy Policy and Conservation Act (EPCA). Public Law 94-163, https://www.energy.gov/eere/buildings/standards-and-test-procedures. (Accessed on June 25 ${ }^{\text {th }}$, 2021).

${ }^{36}$ Department of Energy. Furnaces and Boilers https://www.energy.gov/energysaver/homeheating-systems/furnaces-and-boilers (accessed June 29 ${ }^{\text {th }}, 2021$ ).

${ }^{37}$ U.S. Energy Information Administration. Units and calculators explained. British thermal units (Btu). https://www.eia.gov/energyexplained/units-and-calculators/british-thermal-units.php (accessed on October 13, 2021).

${ }^{38}$ Arguez, A. NOAA's 1981-2010 U.S. Climate Normals: An Overview. Bulletin of the American Meteorological Society 2012, 93 (11), 1687-1697. https://doi.org/DOI.org.

${ }^{39}$ William Liss. Empirical Analysis of Natural Gas Furnace Sizing and Operation; Topical Report GTI-16/0003; Gas Technology Institute: Des Plaines, Illinois, 2016.

${ }^{40}$ Energy Use Calculator. Electricity usage of an Electric Furnace - Energy Use Calculator https://energyusecalculator.com/electricity furnace.htm (accessed 2021 -10 -06).

${ }^{41}$ Office of Energy Efficiency and Renewable Energy, Department of Energy. Energy Conservation Program: Energy Conservation Standards for Residential Central Air Conditioners and Heat Pumps; p 269.

${ }^{42}$ Fairey, P.; Wilcox, B.; Parker, D.S. Climatic impacts on heating seasonal performance factor (HSPF) and seasonal energy efficiency ratio (SEER) for air-source heat pumps. ASHRAE Transactions; Atlanta, 2004, 110, 178-188.

${ }^{43}$ Department of Energy. Electric Resistance Heating https://www.energy.gov/energysaver/electric-resistance-heating (accessed 2021 -10 -07).

${ }^{44}$ ESTES Services. At What Temperature Do Heat Pumps Become Ineffective? https://www.estesair.com/blog/at-what-temperature-do-heat-pumps-become-ineffective/ (accessed $2021-10-10)$.

${ }^{45}$ What Is BTU? Ultimate Guide to BTU Rating 2021 - PICKHVAC. How to Choose Best HVAC Systems.

${ }^{46}$ BTU To kW Converter Calculator - PICKHVAC https://www.pickhvac.com/calculator/btu-to$\underline{\mathrm{kw} /}$ (accessed $2021-10-10)$. 
${ }^{47}$ How Often Should A Heat Pump Cycle Turn On And Off? - SPRSUN Heat Pump Manufacturer https://www.sprsunheatpump.com/How-Often-Should-A-Heat-Pump-Cycle-TurnOn-And-Off-id3844730.html (accessed $2021-10$-10).

${ }^{48}$ Conditioned Air Solutions. "How Long Should My Air Conditioner Run in a Cycle HVACTips." Conditioned Air Solutions, 21 Mar. 2017, https://www.conditionedairsolutions.com/longair-conditioner-run-cycle/.

${ }^{49}$ Energy Information Administration. Degree-days (EIA) https://www.eia.gov/energyexplained/units-and-calculators/degree-days.php (accessed 2021 -10 $-06)$.

${ }^{50}$ Department of Energy. CCMS - Public Database. https://www.regulations.doe.gov/certification-data/CCMS. Accessed on April 1 ${ }^{\text {st }} .2021$.

${ }^{51}$ EPA. ENERGY STAR Product Finder API \& Datasets | EPA ENERGY STAR. https://www.energystar.gov/productfinder/advanced. Accessed 5 Apr. 2021.

${ }^{52}$ Sloan, Healthminder. Model HMA-7000 Aques. 2010. https://www.waterwisetech.net/specs/aqus system_HMA-7000 specifiactions.pdf accessed on June 28, 2021.

${ }^{53}$ Hydraloop. H600. Fact sheet. Residential water recycling. 2021. https://www.hydraloop.com/products. Accessed on June 28, 2021.

${ }^{54}$ Aqualoop single membrane station. https://www.enviromeasures.com/product/aqualoopsingle-membrane-cartridge-station-including-membrane-control-unit/.

Accessed on June 28, 2021.

${ }^{55}$ Jönsson, H.; Baky, A.; Jeppsson, U.; Hellström, D.; Kärrman, E. Composition of urine, faeces, grewater and biowaste for utilization in the URWARE model. 2005 Urban Water Chalmers University of Technology.

${ }^{56}$ Rose, C.; Parker, A.; Jefferson, B.; Cartmell, E. The characeterization of feces and urine: A review of the literature to infrom advanced treatment technology. Critical Rev. in Environ. Sci. Technol. 2015, 45, 1827-1879.

${ }^{57}$ Verstraete, W.; Caveye, P.V.; Diamantis, V. Maximum use of resources present in domestic "used water". Bioresource Technol. 2009, 100, 5537-5545.

${ }^{58}$ Vinnerås, B.; Jönsson, H. The performance and potential of faecal separation and urine diversion to recycle plant nutrients in household wastewater. Bioresource Technol. 2002, 84, 275-282.

${ }^{59}$ Plum Creek Conservation District. 2004. Rainwater collection in cooperation with the Luling Foundation Farm. 
http://pccd.org/rainwc.htm accessed on June 28, 2021.

${ }^{60}$ NREL. National Residential Efficiency Measures Database V3.1.0. 2018, https://remdb.nrel.gov/about.php.

${ }^{61}$ Introduction to Operations Research, $10^{\text {th }}$ edition, McGraw-Hill.

${ }^{62}$ Energy Star. Savings Calculator for ENERGY STAR Qualified Appliances; 2016.

${ }^{63} 2021$ Sprinkler System Installation Cost | Average Cost of Sprinkler System https://www.fixr.com/costs/sprinkler-system (accessed 2021 -08 -23).

${ }^{64}$ Arguez, A. NOAA's 1981-2010 U.S. Climate Normals: An Overview. Bulletin of the American Meteorological Society 2012, 93 (11), 1687-1697. https://doi.org/DOI.org. 